\title{
From the Neolithic to the Bronze Age in Central Italy: Settlement, Burial, and Social Change at the Dawn of Metal Production
}

\section{Andrea Dolfini ${ }^{1}$}

Published online: 20 December 2019

(c) The Author(s) 2019

\begin{abstract}
The Late Neolithic and Copper Age were a time of change in most of Europe. Technological innovations including animal traction, the wheel, and plow agriculture transformed the prehistoric economy. The discovery of copper metallurgy expanded the spectrum of socially significant materials and realigned exchange networks away from Neolithic "greenstone," obsidian, and Spondylus shells. New funerary practices also emerged, signifying the growing importance of lineage ancestors, as well as new ideas of personal identity. These phenomena have long attracted researchers' attention in continental Europe and the British Isles, but comparatively little has been done in the Italian peninsula. Building on recent discoveries and interdisciplinary research on settlement patterns, the subsistence economy, the exchange of socially valuable materials, the emergence of metallurgy, funerary practices, and notions of the body, I critically appraise current models of the Neolithic-Bronze Age transition in light of the Italian regional evidence, focusing on central Italy. In contrast to prior interpretations of this period as the cradle of Bronze Age social inequality and the prestige goods economy, I argue that, at this juncture, prehistoric society reconfigured burial practices into powerful new media for cultural communication and employed new materials and objects as novel identity markers. Stratified political elites may not be among the new identities that emerged at this time in the social landscape of prehistoric Italy.
\end{abstract}

Keywords Prehistoric Europe $\cdot$ Social archaeology · Inequality · Late Neolithic · Copper Age $\cdot$ Chalcolithic $\cdot$ Italy

Andrea Dolfini

andrea.dolfini@ncl.ac.uk

1 School of History, Classics and Archaeology, Newcastle University, Armstrong Building,

Newcastle upon Tyne NE1 7RU, UK 


\section{Introduction}

In much of Europe, the late fifth to the late third millennia $\mathrm{BC}$ was characterized by four sweeping changes that fundamentally altered the fabric of Neolithic society (Broodbank 2013; Heyd 2007; Kristiansen 2015; Robb and Harris 2013; Whittle 1996). The first was the gradual transformation of landscapes of settlement, as long-lived villages were generally abandoned, and more mobile economic regimes and lifestyles emerged. The second, occurring in lockstep with the first, was the new prominence of burial as a social practice, including the establishment of formal cemeteries, new funerary structures (e.g., megaliths and chamber tombs), and mortuary rites that centered on two seemingly contrasting principles: the breaking up and mixing of ancestors in collective tombs, and the expression of personal identity in individual burials. The third was the intensification of human mobility and social interaction, as evidenced by the long-distance exchange of prized materials such as Alpine "greenstone" and obsidian, as well as population movement on a scale not seen since the Mesolithic-Neolithic transition (Kristiansen et al. 2017). The fourth was a suite of technological innovations of which metalworking was certainly the most conspicuous but that also encompassed the harnessing of animal power for plowing and wheeled transport. New domesticates also were introduced at this time-the donkey in the eastern Mediterranean and the horse in most of Europe-and old domesticates were put to new uses, ushering in what Sherratt $(1981,1983)$ famously termed the "secondary products revolution."

Notwithstanding the many countertrends visible in the regional record (e.g., large fortified settlements in Iberia; Garcia and Murillo-Barroso 2013), these entwined material and social transformations seemingly affected, with varying intensity, all late Neolithic and Chalcolithic societies from northern Europe to the Mediterranean and from the Balkans to the Atlantic façade. They have long invited social, economic, and political explanations.

Culture historians traditionally explained the change by invoking population movement, the spread of ideas, and the introduction of new technologies, first and foremost copper metallurgy (Childe 1957; Gimbutas 1977; Puglisi 1959). Childe (1957), in particular, maintained that metals would have triggered a profound transformation in European society by enabling accumulation, exchange, and inheritance of valuables at an unprecedented scale, under the stimulus of early Mesopotamian urban centers. His views have had a lasting fortune in prehistoric studies, inspiring historical materialist models that are being debated to this day. Central to them is the belief that metals and related prestige goods would enable the creation of ranked societies, in which power was either fought over through male peer competition or inherited by descent. Long-distance trade, control of material resources, and coercion were seen as some of the key mechanisms driving the sociopolitical transformation of Neolithic Europe toward systemic inequality (e.g., Chapman 2003; Gilman 1991; Kristiansen 2015). These ideas have cast a long shadow in archaeological discourse. Over the years, they have been rephrased according to different theoretical standpoints. 
Working within (broadly defined) postprocessual frameworks, Shennan (1982), Thorpe and Richards (1984), and Braithwaite (1984) maintained that late Neolithic Europe underwent fundamental changes in the nature of social relations. These entailed the replacement of large-scale collective rituals centering on competitive consumption with more individualized forms of prestige, expressed by weaponry and other prized personal possessions. Building on these readings, Barrett (1994) and Thomas (2002) stressed that changes in social relations were mediated by a new emphasis on individual burial, away from the notions of collective ancestry typical of Neolithic mortuary practices. For many, rank (expressed by prestige goods) and genealogy (expressed by new burial rites) were interlocked. Historical materialists such as Peroni $(1989,1996)$ and Guidi (2000) saw both strategies as being jointly used by emerging elites to legitimize the acquisition and transmission of power, laying the foundations of hierarchical Bronze Age society.

Other authors focused on the economic transformation of late Neolithic and Chalcolithic Europe. Sherratt $(1981,1983)$, in particular, posited that the introduction of woolly sheep, plow agriculture, and animal traction from the Near East would have resulted in dramatic changes in sociopolitical organization. In his view, these innovations led to a revolution in subsistence strategies, superregional exchange, and settlement patterns, sowing the seeds of the interconnected Bronze Age "world system" (Sherratt 1993). Though very influential, Sherratt's model was later shown to compress into a relatively short period a broad suite of economic and technological transformations that occurred, in a staggered fashion, over thousands of years (Greenfield 2010). It also was criticized for being a new iteration of old-school Ex Oriente Lux readings that created an unwarranted dichotomy between dynamic Near Eastern urban civilizations and stagnant European agrarian societies (Robb 2007, p. 288).

The most recent scholarship on the subject divides into two broad strands: social constructionist models and neodiffusionist interpretations. The first is championed by Robb (2007) and Robb and Harris (2013), among others (e.g., Fowler 2018). Having critiqued all previous paradigms for their reliance on a prime mover of sorts, Robb (2007) grounded his reading in cross-cultural mechanisms of social reproduction. Following Bourdieu (1977), he argued that change may result from myriad acts of realignment and repositioning of knowledgeable actors within overarching social structures. From this theoretical standpoint, he proposed that late Neolithic society would be marked by new forms of value that were appropriated by emerging political leaders for self-promotion. Working within a similar interpretative framework, Robb and Harris (2013) further suggested that the new value system would have hinged on a binary gender ideology. This was expressed though a suite of media including individual burial, anthropomorphic statuary, and a new "body technology": metals.

At the other end of the interpretative spectrum are several authors who champion a new synthesis of culture history, language studies, and archaeological science. Their controversial opinions have triggered a heated debate that shows no signs of abating (Furholt 2018; Heyd 2017; Hofmann 2015; Vander Linden 2016). The first salvo was fired by Mallory (1989). He revived early culture historians' proposals that a wave of migrant pastoralists from the Pontic-Caspian steppe would have swept 
through Europe in the third millennium BC, bringing with them new domesticates and economic practices, new technologies, and the Indo-European language (see also Anthony 2007). Recent breakthroughs in ancient DNA analysis have stoked the fires of the cross-disciplinary controversy. The new research has sought to link the spread of certain genetic traits throughout continental Europe and the British Isles with the diffusion of Yamnaya, Corded Ware, and Bell Beaker cultural groups from the late fourth millennium BC. Some scholars have also tied these migratory events to the diffusion of early Indo-European languages (Allentoft et al. 2015; Haak et al. 2015; Kristiansen et al. 2017; Olalde et al. 2018).

With few exceptions, the models and interpretations discussed above are grounded in the archaeology of continental Europe and the British Isles. Central among them are cultural phenomena that may be marginal or absent in Mediterranean Europe, including the Italian peninsula. For instance, Bell Beaker burials and objects are present (if not necessarily widespread) in northern Italy but are rarely found south of the Arno Valley, Tuscany (Sarti and Martini 2001). Similarly, individual "warrior" burials are often linked to the spread of Corded Ware, Bell Beaker, and related cultural phenomena (and perhaps to the arrival of new people) in third millennium BC Europe (Harrison and Heyd 2007; Heyd 2017), but they emerged in Italy in different cultural contexts that date to the mid-fourth millennium BC (Dolfini 2010; Jeunesse 2014). Barring earlier, yet undetected "cultural stimuli" or population movements from north/central Europe or the Eurasian steppes, it is hard to see how the two phenomena are connected. Similar observations have been put forward regarding the alleged eastern European connections of the Iberian Chalcolithic (Guilaine 2018).

Under these circumstances, Mediterranean Italy provides a useful arena for testing broad cultural trends and interpretative models in European prehistory as a whole. To what extent do they apply to this region? In what direction does Italy "look" at this time? North, across the Alps, or south, across the water? Does it look in any direction at all? The region is particularly well suited as a testing ground thanks to a host of recent discoveries and research advances that have not yet seeped into the international Anglophone literature. Nowhere has this outburst of study been more apparent than in central Italy, where numerous new sites have been excavated and old excavations published. Focusing my multiscalar analysis on central Italy (drawing in data and comparanda from other parts of Italy as relevant and appropriate) allows me to work at the interface between local and superregional social dynamics that may be lost in the study of a broader area. Central Italy is not an arbitrary unit of analysis, but one that has a long pedigree in Italian prehistoric studies (e.g., Barker 1981; Guidi and Piperno 1992; Peroni 1996; Pessina and Tiné 2008). Due to its elongated geography and rugged morphology, Italy historically shows diverging cultural trajectories in the north, center, and south. More often than not, these have a longue durée stretching back into prehistoric times, thus making regional examinations of this kind all the more apposite (Horden and Purcell 2000).

Chronologically, I focus on 4500-2200 BC, known as the late Neolithic and Copper Age (or Eneolithic) in Italian periodization. Despite the recent surge of interest in the archaeology of this period, specialists have not yet reconsidered to what extent the new data may be harmonized into established interpretations. Two problems, in 
particular, stand in the way of novel conceptualizations of this period. The first is a tendency to narrowly concentrate on specific themes and subjects, paying scant attention, if any, to how new data affect the broader picture. The second is a scholarly predisposition to discuss the Late Neolithic and Copper Age as separate phases. Even when attempts are made to cross the divide (e.g., Robb 2007; Whittle 1996), Neolithic specialists read the sequence from their particular vantage point, which construes the Copper Age as a hyper-evolved late Neolithic. Conversely, Copper Age specialists treat the mid-fourth millennium BC as an impassable cultural watershed, thus failing to investigate late Neolithic social dynamics and how they paved the way for the Chalcolithic world.

My aim is to provide a fresh picture of central Italy from 4500-2200 BC, in which different strands of evidence are cross-interrogated and critically combined. I also offer a coherent view of the entire sequence, devoid of the disciplinary biases decried above. I highlight continuities as well as discontinuities in the material and social dynamics of the two phases, focusing in particular on the natural environment and landscape, the chronological and cultural sequence, settlement and the subsistence economy, connectivity and exchange, the emergence of metallurgy, and funerary practices and ideas of the body. I conclude with a critical reappraisal of Late Neolithic and Copper Age sociopolitical dynamics, followed by reflections on where future research ought to be steered.

\section{The Natural Environment and Landscape}

Central Italy is the middle section of the boot-shaped Italian peninsula, comprising (north to south, in clockwise order) modern-day Marche, Abruzzo, Lazio (Latium), Umbria, Toscana (Tuscany), and eastern Liguria (Fig. 1). Liguria is normally thought to belong to northern Italy, but I include it in this review as it arguably had close cultural ties with Tuscany in the period under examination (limited to its eastern part). In the north, central Italy is demarcated by the uppermost tract of the Apennines, a major mountain range that is the natural backbone of the peninsula. In the east and west, it is bounded by the Adriatic and Tyrrhenian Seas, respectively. In the south, it is somewhat artificially defined by the modern administrative borders of Latium and Abruzzo, which provide a boundary of sorts with the southern peninsula. The region is extraordinarily varied in landforms, encompassing low coastal plains and marshlands (now largely reclaimed), areas of rolling hills, wide river basins that provide highways for human mobility (e.g., the Arno and Tiber Valleys), steep crags and ravines in the volcanic landscapes of southern Tuscany and northern Latium, and snow-capped peaks and intermontane basins in the central Apennines (Barker 1981; Walker 1967).

The region is part of a broad biogeographical zone that comprises the northwestern quadrant of the Mediterranean basin (Blondel et al. 2010). Climatically, it has hot, dry summers and mild to cool winters, when most of the rain falls. However, variation is great due to both morphology and altitude. The Tyrrhenian and Adriatic lowlands are characterized by fall and winter rainfall maxima, while summers can be extremely dry. In contrast, the Apennine uplands are prone to cooler and 
Fig. 1 Map of sites mentioned in the text: 1, Valle di Castiglione; 2, Quadrato di Torre Spaccata; 3, Piscina di Torre Spaccata; 4, Fosso Conicchio; 5, Casale del Cavaliere; 6, Le Cerquete-Fianello; 7, Tor Pagnotta; 8, Casale di Valleranello; 9, Maddalena di Muccia; 10, Selva dei Muli; 11, Poggio Olivastro; 12, Prato Mollo; 13, Querciola; 14, Casale del Dolce; 15, Conelle di Arcevia; 16, Lavagnone; 17, OssimoAnvoia; 18, Saint-Martin-de-Corléans; 19, Ortucchio; 20, Grotta dei Cervi; 21, Monte Arci; 22, Lipari (Acropolis, Contrada Diana, and obsidian quarries); 23, Palmarola; 24, Pantelleria; 25, Valle Lagorara; 26, Prima Ciappa; 27, Pianaccia di Suvero; 28, Orti Bottagone; 29, San Carlo-Cava Solvay; 30, Libiola; 31, Monte Loreto; 32, Poggio Malinverno; 33, Buca di Spaccasasso; 34, The Iceman; 35, Zug-Riedmatt; 36, Masseria Bellavista; 37, Scoglio del Tonno; 38, Cala Tramontana; 39, Arnesano; 40, Serra d'AltoFondo Gravela; 41, Ripoli; 42, Grotta dei Piccioni; 43, Botteghino; 44, Grotta San Giuseppe; 45, Grotta del Fontino; 46, Pontevecchio; 47, Minucciano; 48, Parma-Via Guidorossi; 49, Rapolano; 50, Ponte San Pietro; 51, Catignano; 52, Gricignano d'Aversa (base map: Ancient World Mapping Center)

wetter summers. Much of the high-altitude zone experiences subalpine winter temperatures. Here, deep snow frequently covers the mountain ridges and high pastures from October to April, and a glacier nestles within the Corno Grande, the highest peak of the Apennines (Grunewald and Scheithauer 2010; Walker 1967).

Broadly speaking, vegetation patterns follow the morphological and altitude categories outlined above. The eastern and western lowlands are home to coastal forests and shrublands featuring a mixture of holm oak (Quercus ilex), cork oak (Quercus suber), and other evergreen species. The intermediate zone, between about 500 and $1000 \mathrm{~m}$ above the sea level, is dominated by sub-Mediterranean deciduous woodlands comprising hazel (Corylus), elm (Ulmus), and various species of oak. The mountain zone above $1000 \mathrm{~m}$ features majestic forests of beech (Fagus sylvatica) as well as the last remnants of conifers, which are especially rich in fir (Abies) (Barker 1981, pp. 21-23; Walsh 2014).

In the Early and Middle Neolithic (c. 5800-4500 BC), the region benefited from the relatively stable conditions brought about by the Early Holocene climatic optimum, which was characterized by warmer-than-average temperatures and higherthan-average precipitation rates, although variation was great depending on both latitude and altitude (Davis et al. 2003). This changed dramatically in the Late Neolithic and Copper Age, which were affected by a marked drier turn. In central Italy, the Mid-Holocene climatic deterioration is evident in several proxies including pollen spectra and lake levels, which all point to the slow but inexorable contraction of the native woodlands. This was not only caused by climate change but also by the first episodes of forest clearance and woodland management (Allen 2003; Branch and Marini 2014; Giraudi et al. 2011; Magny et al. 2007; Walsh 2014). The process can best be followed in the pollen diagram from Valle di Castiglione (Rome) and is further confirmed, in its broader trends, by other pollen spectra from the region (Colombaroli et al. 2007; Magri and Sadori 1999; Sadori et al. 2011). At Valle di Castiglione, the Early Holocene expansion of deciduous species peaked in the mid/late fourth millennium $\mathrm{BC}$, followed by a contraction of the tree cover and the expansion of cereals and other herbaceous plants brought about by combined aridity and forest clearance (Follieri et al. 1989).

Although initially limited in its wider environmental effects, forest clearance triggered the first episodes of soil erosion and the earliest occurrences of progradation, or coastline advancement, due to increased sediment accumulation at river 


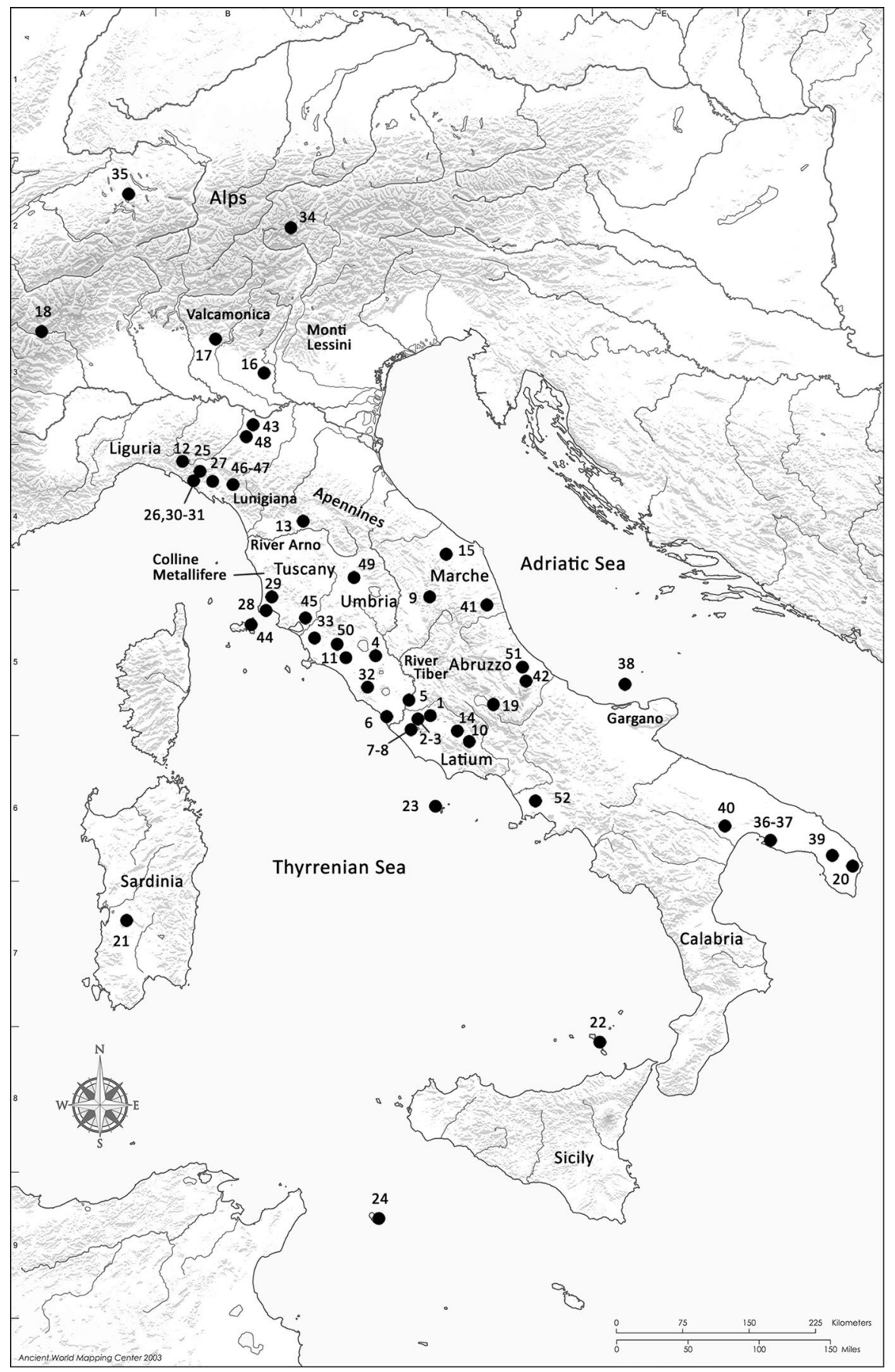


mouths and the Early Holocene sea-level rise slowing to a halt (Barker et al. 1990; Bellotti 2017; Coltorti 1997; Roberts et al. 2011). For the first time, pastures were carved into the forested uplands, and woods were actively managed to provide sustenance for people and livestock. The process is especially visible at Prato Mollo, a high-altitude peat site in eastern Liguria. Here, pollen analysis has revealed that the native tree cover dominated by silver fir (Abies alba) retreated significantly from the early third millennium BC due to multiple wildfires. The forest was replaced by grassland and open beech (Fagus) woodland - a species ostensibly promoted as it provides excellent cattle fodder. Tree cover deterioration is further confirmed by soil analysis, which yielded plentiful evidence of peat formation, erosion, and waterlogging (Maggi and De Pascale 2011). These phenomena are motivated by sweeping changes in prehistoric subsistence practices. Before discussing those changes, I first clarify the chronological and cultural sequence as defined by radiocarbon and ceramic assemblages.

\section{Chronology and Cultural Sequence}

\section{Absolute Chronology}

For most of the 20th century, archaeologists utilized pottery styles to construct chronological and cultural sequences for later Italian prehistory. Their work was predicated upon the unspoken assumption that ceramic styles neatly succeeded one another and could, therefore, be taken to represent discrete chronological phases and cultural groups (Radmilli 1975; Trump 1966). The fall of culture history as a theoretical paradigm and the spread of independent means of dating showed the inherent limits of this approach. Scholars then realized that changes in pottery styles need not be synchronous or evenly spread across bounded territories, and that conventional ideas of the "archaeological culture" (sensu Childe 1929, pp. v-vi) no longer reflected the growing complexity of the material record. This state of affairs elicited different responses in the Anglophone and Italian/continental scholarship. By and large, the former lost interest in the minutiae of ceramic typology and shifted their research to social issues such as the prehistoric economy, prestige goods exchange, and burial practices (e.g., Barker 1981). The latter, on the other hand, doubled their efforts to build ever more sophisticated chronological frameworks based on the evolution and spread of pottery styles. Over time, this evolved into a hyperspecialized and, for many, arcane research strand (e.g., Cocchi Genick 1994, 1996, 2008).

Regardless of their interest in pottery styles, however, both communities continued to share the broad chronological edifice framing their studies. Until relatively recently, all students of Italian prehistory dated the Late Neolithic to the fourth millennium BC and the Copper Age to the third millennium BC (Cocchi Genick 2013a, p. 234). The status quo was first challenged in the 1990s when absolute dating methods highlighted major inconsistencies with the established framework. Research carried out in the last 20 years has all but clarified the overall chronology of the period in question, showing that the Late Neolithic began in mid-fifth millennium $\mathrm{BC}$ and the Copper Age a thousand years later. The two periods are separated by 
a short-lived Final Neolithic phase in the early fourth millennium BC. Despite the significant progress made, however, specialists still disagree about the exact duration of each phase, as well as about the identification and precision dating of discrete subphases within them (compare, e.g., Leonini et al. 2013 and Negroni Catacchio et al. 2014).

The Late and Final Neolithic chronology proposed here is built on Pessina and Tiné (2008), although I favor a slightly later boundary between the two phases than what they suggest; this better accounts for the central Italian record. The onset of the Copper Age is placed at 3600 BC based on the Bayesian model developed by Maggi and Pearce (2013), while the tripartite subdivision of the period is modeled on Skeates (1996), modified to account for recent AMS dating (e.g., Anzidei et al. 2012; Cocchi Genick 2013b; Dolfini 2010; Manfredini et al. 2009). The end of the Copper Age is placed at $2200 \mathrm{BC}$, bearing in mind that certain Chalcolithic technological and cultural practices (e.g., arsenical copper metallurgy and burial in caves) continued into the Early Bronze Age. This chronology has an overall tolerance of \pm 100 years due to the confidence range of most radiocarbon dates (Table 1).

\section{Pottery Styles and Their Social Interpretation}

Despite the firm ground created by radiocarbon, a great many old excavations, and much recent developer-funded fieldwork, lack absolute dates. For these sites, pottery still is an indispensable chronological tool, notwithstanding the limitations highlighted above. Stylistic classification is especially useful when pottery designs have relatively well-defined temporal and territorial boundaries, as is often the case in the Late Neolithic. The picture blurs and complicates in the Final Neolithic and Copper Age, when various ceramic traditions coexisted for hundreds of years, mingling and overlapping in complex and ever-shifting ways. Even in these periods, however, pottery still supplies valuable chronological and cultural data to specialists.

In the latter part of the fifth millennium BC, Middle Neolithic incised and painted wares were replaced by new, shallow forms of ceramic vessels with plain burnished surfaces. This regional trend reflects a generalized change in aesthetic principles that was in operation throughout most of Mediterranean Europe (Broodbank 2013; Robb 2007). The new preference for wider vessels and glossy surfaces is apparent in all three ceramic styles found in Italy at this time: Chassey-Lagozza (a variant of the French Chassey style) in the northwest; Late Ripoli in the east; and Diana in the south (Cocchi Genick 2009; Malone 2003; Pessina and Tiné 2008).

Table 1 Relative and absolute chronology of prehistoric central Italy, 4500-2200 BC

\begin{tabular}{ll}
\hline Archaeological phase & Absolute chronology \\
\hline Late Neolithic & $4500-3800 \mathrm{BC}$ \\
Final Neolithic & $3800-3600 \mathrm{BC}$ \\
Early Copper Age & $3600-3300 \mathrm{BC}$ \\
Middle Copper Age & $3300-2700 \mathrm{BC}$ \\
Late Copper Age & $2700-2200 \mathrm{BC}$ \\
\hline
\end{tabular}


The central peninsula is split east-west in its cultural manifestations. Late Ripoli wares are ubiquitous east of the Apennines (Cremonesi 1965). They feature shallow bowls and plates as well as deep vases that anticipate Copper Age flasks and bottles. Pots were normally plain and burnished to a gloss, but a new taste for textured and rough surfaces emerged in the latter part of the phase, as did a marked tendency toward regionalization. At the same time, however, the shapes and decorative choices of vessels were increasingly open to superregional influences, including, for example, the incorporation of Chassey-Lagozza and Diana elements into Late Ripoli repertoires (Pessina and Radi 2002, 2003; Pessina and Tiné 2008).

West of the Apennines, domestic sites have yielded idiosyncratic assemblages consisting of ceramic styles from the northern, eastern, and southern peninsula (Fig. 2). It is not uncommon for vessels in the Chassey-Lagozza, Late Ripoli, and Diana styles to be found, all at once, at the same site. Strikingly, these styles are often recombined and amalgamated locally so that it is almost impossible to find two Late Neolithic settlements bearing the same ceramic fingerprint (Cocchi Genick 2009, p. 174). At Quadrato di Torre Spaccata, for instance, Diana finewares, with their buff red-slipped surfaces and rocchetto (spool shaped) handles, are found alongside shallow bowls and plates in the Chassey-Lagozza style, as well as vessels in various Late Ripoli regional groups (Anzidei and Carboni 1995; Anzidei and Zarattini 2007). As with coeval evidence from Adriatic Italy, this puzzling state of affairs can be explained by a seemingly contradictory move toward regionalization and superregional interaction, although the material outcome is here entirely peculiar. This trend progressed further in the Final Neolithic, which featured the continued development of eclectic, highly localized ceramic assemblages, as well as the near-complete substitution of coarse impasto vessels for burnished finewares (Anzidei et al. 2002; Sarti et al. 2005; Silvestrini et al. 2002).

The onset of the Copper Age is marked by a "perfect split" between domestic and funerary pottery on both sides of the central peninsula, and indeed farther north and south. On the one hand, the new taste for coarse wares with textured surfaces continued at open villages and other habitation sites. Building on previous developments, Copper Age domestic ceramics were shaped and ornamented according to a bewildering variety of stylistic traits, which household and village potters blended into original material assemblages (Cocchi Genick 2008). On the other hand, the Late Neolithic preference for burnished surfaces was carried, unabated, into the mortuary realm. The bottles, flasks, and bowls now placed with the dead followed normative stylistic conventions shared over large areas. It is as though the ceramic unity of the Late Neolithic world, smashed to pieces in the domestic arena, had been recreated for the benefit of the dead.

Bell Beaker pottery was introduced into the region in the Late Copper Age, most notably in the Arno Valley and along the middle Tyrrhenian coast (Bulgarelli et al. 2000; Sarti 1995-1996, 1997, 1998). Apart from a handful of burials from these areas, Beaker-style vessels and accoutrements were rarely used in the realm of the dead. Out of over 100 chamber tombs excavated in inner central Italy, only one has yielded Beaker pottery (Negroni Catacchio and Miari 1995; Petitti et al. 2002). There is, however, one notable exception to this quasi-universal pattern: Fosso Conicchio in northern Latium. The site consists of a subcircular sunken pit $1.75 \mathrm{~m}$ deep and $3.10 \mathrm{~m}$ across, 


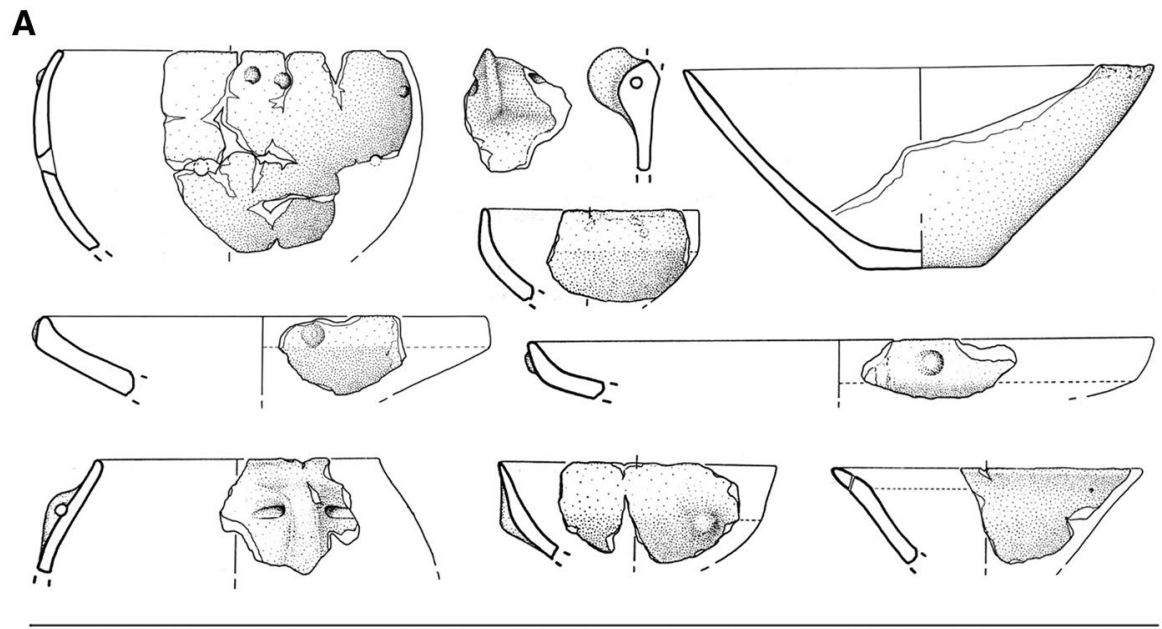

B
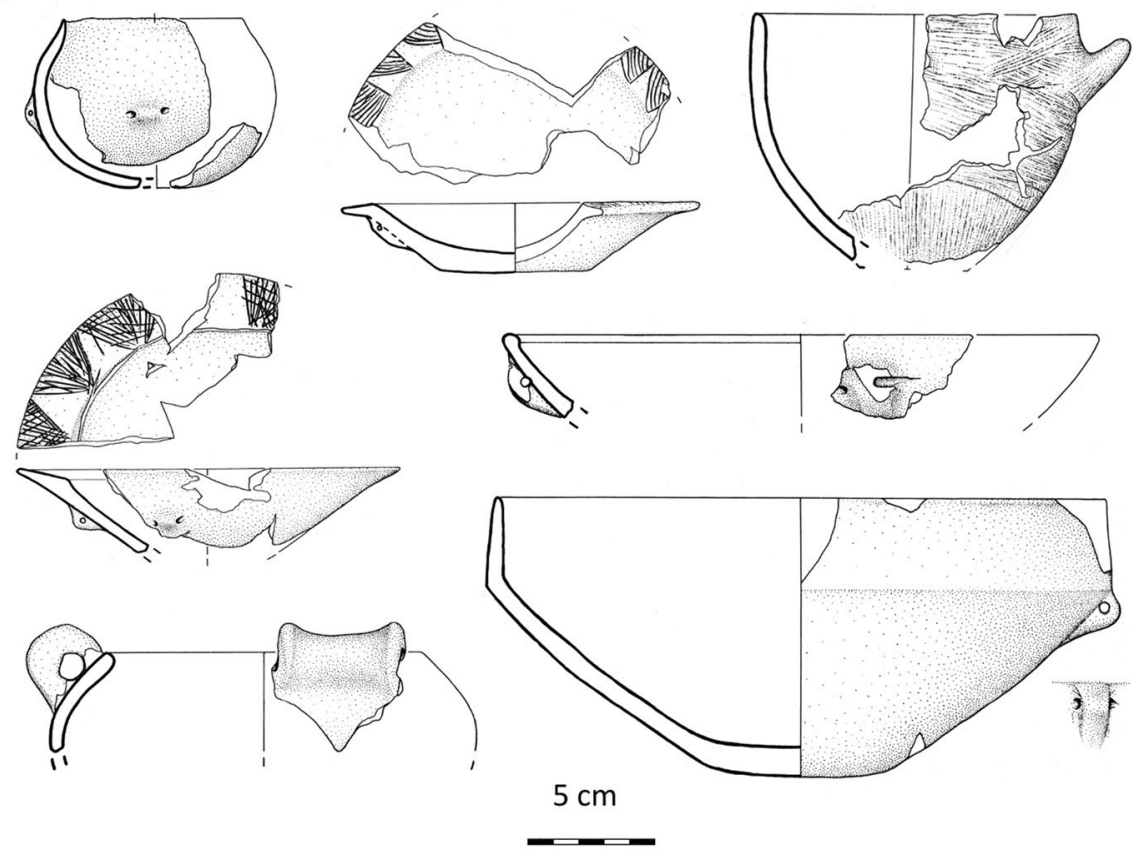

Fig. 2 Late Neolithic ceramic styles from west-central Italy: A, Late Ripoli pottery from Casale di Valleranello, Rome; B, pottery from Quadrato di Torre Spaccata, Rome, mostly in the northern ChasseyLagozza style, but the bottom left vessel has a rocchetto (spool-shaped) handle typical of southern Diana wares (image: Giovanni Carboni)

cut into the limestone bedrock. As it lacks any evidence of roofing, the pit was seemingly accessed from the top, perhaps using a wooden ladder. To one side of the structure lies a trapezoidal altar-like platform hewed into the rock. This provided a focus for 
rituals involving the placement of lavishly decorated Beaker vessels, Beaker-style wrist guards, human teeth, and cremated human remains (Fugazzola Delpino and Pellegrini 1999). The site is entirely out of character for this area, dominated by Rinaldone-style chamber tombs (see below). Fosso Conicchio should not be considered a burial site proper but a locus for the ritual processing of ancestral remains. This underscores the impression that, in Copper Age Italy, choices regarding pottery styles were predicated upon the practices in which the vessels were meant to be used and cannot be reduced to abstract notions of the "archaeological culture."

The pulverization of ceramic styles and clear-cut separation between domestic and funerary pottery is not exclusive to central Italy. Other regions of Europe experienced similar phenomena in the fourth millennium BC. In southern France, for example, the late Neolithic Chassey "culture" was replaced from 3500 BC by multiple small-scale ceramic styles featuring, like in central Italy, impressive intergroup variation as well as superregional influences (Gutherz and Jallot 1995; Vaquer 1990). According to Vander Linden (2006), the change reflects growing sociopolitical tensions between increasingly fragmented communities. He argues that a novel emphasis on weapon burials, high rates of skeletal trauma, and the expansion of drystone defensive architecture would further highlight intercommunity friction in a fast-changing social landscape.

It is unclear if this reading may apply to central Italy given the lack of recent, theoretically informed research into Copper Age pottery styles in the region. My interpretation, though not yet supported by dedicated research, tentatively moves in a different direction. Rather than demarcating more localized forms of group identity, the breakup of domestic ceramic styles might, in fact, stem from a dramatic deflation of their social significance. In the Neolithic world, finewares were utilized at villages in core social reproduction practices such as feasting and burial (Robb 2007; Skeates 1995a). Though mostly made and used locally, the pots were built and decorated according to widespread stylistic conventions, which were probably shared via the extensive exchange networks in operation at the time (see below). In the fourth and third millennia $\mathrm{BC}$, domestic pottery was no longer employed in identity-building social interactions, for these were now carried out at burial sites using vessels that, like Neolithic domestic pottery, were ornamented based on widely shared aesthetic principles; these are rarely found at habitation sites. Bereft of its former social significance, domestic pottery was downgraded to crockery, expediently built and mundanely used-hence its bewildering variety of styles, likely reflecting village-based (and perhaps household-specific) craft traditions. Still, village communities continued to relate with one another, as the sharing of decorative motives indicates. This offers tantalizing glimpses into yet unexplored patterns of interaction within selfcontained communities of practice.

\section{Settlement and the Subsistence Economy}

In several regions of Europe, the late fifth to late third millennia $\mathrm{BC}$ is characterized by the decline of the village as the center of people's identity and social life, and the rise of the extramural cemetery. This is paralleled by the introduction of more 
mobile lifestyles and economic regimes that were increasingly reliant on livestock and their secondary products (Broodbank 2013; Whittle 1996). In central Italy, there were three broad changes in landscapes of settlement and subsistence strategies. The first is the abandonment of long-lived Neolithic villages, which were progressively replaced by dispersed settlements, isolated farmsteads, and seasonally inhabited caves and open stations. The second is the expansion of human activity from arable lowlands and river terraces into marginal landscapes such as uplands, high mountains, and coastal and riverine wetlands. The third is a shift toward more diversified economic practices based on mixed farming, herding, and hunting (Barker 2005; Robb 2007; Skeates 1997a, 2013).

A tendency toward settlement dispersal first manifested itself in the fifth millennium BC, when sizable villages with long occupation spans (e.g., Catignano; Tozzi and Zamagni 2003) were progressively replaced by short-lived, insubstantial settlements, whose archaeological footprints often amount to nothing but pits, cobblestones, and hearths (Fugazzola Delpino et al. 2003; Grifoni Cremonesi 2003b; Grifoni Cremonesi et al. 2001; Manfredini et al. 2005a). This trend continued into the fourth and third millennia BC. At Quadrato di Torre Spaccata (Fig. 3), for example, the Copper Age village consists of two elliptical houses, a rectangular wattle-anddaub building, and other minor structures, all inhabited at the same time (Anzidei and Carboni 1995, 2007). At Casale del Cavaliere, excavations revealed an isolated farmstead occupied for maybe one or two generations, as indicated by the lack of superimposed features and the high number of refitting sherds (Boccuccia et al. 2000). Le Cerquete-Fianello, a small village on the edge of the now-drained Maccarese lagoon, seems at first glance more substantial. However, the stratigraphic analysis of its five wattle-and-daub houses has revealed three building phases spanning, one may speculate, no more than 200 years (Manfredini 2002).

The demise of the nucleated village was long believed to be caused by growing seasonal mobility and intensified pastoralism, especially in the Apennine uplands (Barker 1981; Maggi 2002; Maggi and De Pascale 2011). Recent research has nuanced this picture by showing that large village communities continued to thrive during the Copper Age and that lowland alluvial plains and river valleys were often cultivated more intensively than ever before. This interpretative shift was spearheaded by a series of spectacular discoveries from the northern and southern peninsula. North of the Apennines, the habitation site at Parma-Via Guidorossi has solidly built houses up to $52 \mathrm{~m}$ in length (Bernabò Brea et al. 2011, 2013). Farther south, open-area excavations in the hinterland of Naples (e.g., at Gricignano d'Aversa) brought to light an intensively inhabited landscape in which villages and cemeteries were encased within a mosaic of plowed fields, water wells, and dirt roads (Fugazzola Delpino et al. 2007; Laforgia and Boenzi 2011; Saccoccio et al. 2013). This picture is compounded by numerous, if not quite so dazzling, discoveries from central Italy. Suffice here to mention the large elliptical houses at Tor Pagnotta and the conspicuous ditches and palisades surrounding Maddalena di Muccia and Selva dei Muli (Anzidei et al. 2011a; Cerqua 2011; Manfredini et al. 2005b). In the fertile lowlands, sustained landscape infilling seemingly took place in the Copper Age, as shown by settlements lying closer to one another than in previous periods. It is unclear, however, if this is evidence of population growth, for it might be 


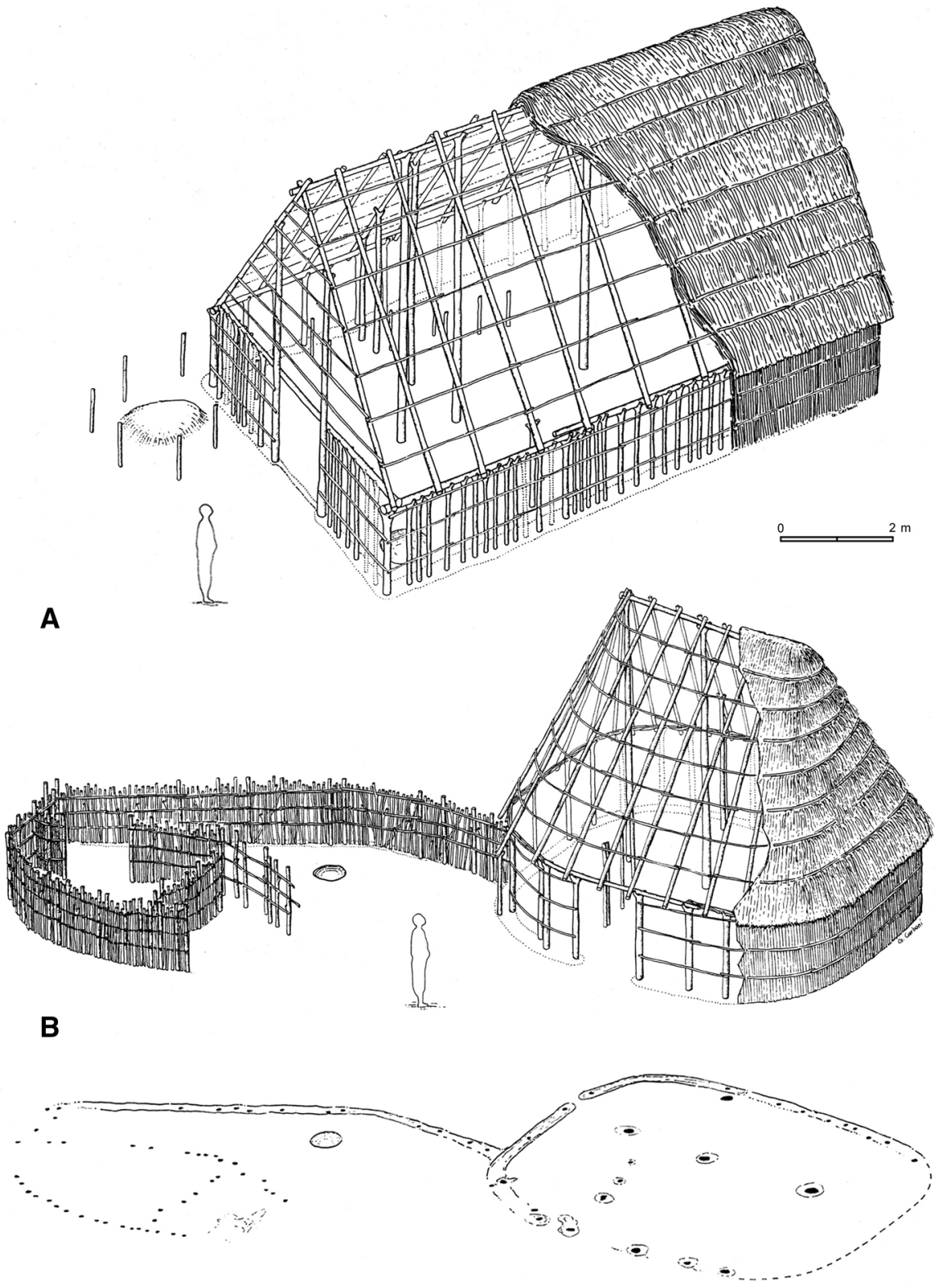

Fig. 3 Wattle-and-daub houses from Quadrato di Torre Spaccata, Rome. Many late Neolithic and Copper Age habitation sites consist of small clusters of houses, a far cry from the substantial nucleated villages of the early and middle Neolithic (Anzidei and Carboni 2007) 
the archaeological footprint of smaller communities moving periodically to nearby unexploited soils (Gianni 1991; Moscoloni and Silvestrini 2005).

At face value, the evidence seems to point to a higher degree of continuity with the Neolithic economy and lifestyle than previously surmised. If we scratch the surface, however, clues soon emerge that there might be more to this than meets the eye. It has long been suggested that certain upland villages including Conelle and Ortucchio may be aggregation sites, in which scattered communities would gather seasonally to exchange livestock and goods, arrange marriages, and hunt red deer and wild boar during youth initiation rites (Robb 2007; Skeates 1997a). However, interpretation is complicated by the state of the evidence. At Conelle, for example, all cultural materials come from the ditch deposit, as the habitation layers were all but wiped out by plowing and erosion (Cazzella 1999). There might also be a hitherto underestimated chronological element to the changes in settlement patterns, with permanent villages becoming rarer in the late fifth and fourth millennia BC and growing again in the third millennium BC, possibly due to new farming technologies that enabled population growth (see below). This is something that future research and radiocarbon dating ought to clarify.

In central Italy, the Copper Age undoubtedly featured sustained colonization of previously marginal landscapes due to the combined effect of climate change, a cultural shift toward mobility and social fragmentation, and the introduction of new farming and breeding practices. Similar trends toward upland frequentation and forest clearance are evident, from the late fourth millennium BC, in the remainder of the peninsula (and indeed farther afield), thus indicating the systemic nature of the changes afoot (Broodbank 2013, pp. 306-309; Cremaschi et al. 2011). Those taking to the mountains relied on new subsistence strategies involving small-scale transhumance from winter lowland pastures to summer upland grazing areas. A host of upland cave stations in which bone profiles, micromorphology, and phytolith analysis all converge show that cattle and sheep/goats provided the economic and social foundations for specialized animal husbandry (Barker 1981; Barker and Grant 1991; Maggi 1997, 2002; Skeates 1997b). Evidence of winter camps is harder to come by, with the possible exception of Le Cerquete-Fianello, a lagoon-side village near Rome. Here, sheep and goat make up almost $60 \%$ of the bone sample, while cereal farming was not practiced on any significant scale. That the local economy narrowly depended upon a few domestic species is further suggested by the absence of fish and game; this is all the more surprising considering that the village sat in an environmental niche exceptionally rich in both (Manfredini 2002). However, interpretation is complicated by nontranshumant pigs in the bone assemblage (c. $20 \%$ of the NISP), compounded by significant preservation biases.

At most lowland and mid-altitude sites, cereal and pulse remains, as well as evidence of food storage and processing, indicate that the intensification of herding did not come at the expense of mixed farming (Skeates 2013). The implication is that the new regime may have required nothing but the short-range movement of herds in the inhabited landscape, or that only a fraction of the populace left for the mountains seasonally. Diversification of subsistence practices, rather than a single-minded move toward pastoralism, is what the data seem to indicate. Along with communities specializing in sheep and goat rearing (e.g., Quadrato di Torre Spaccata and Poggio 
Olivastro; Anzidei and Carboni 1995, 2007; Bulgarelli et al. 1993), there were others relying more heavily on cattle (e.g., Piscina di Torre Spaccata, Querciola, and Casale del Dolce; Bietti Sestieri and Gianni 1984; Bistolfi and Muntoni 2000; Sarti 1997). A few villages intensified pig keeping, but always as part of diverse livestock management strategies comprising other domesticates as well (e.g., Conelle: Cazzella and Moscoloni 1999; Wilkens 2000).

Cattle were increasingly accumulated as a social valuable, enabling owners to build up and repay debts and obligations (Robb 2007, p. 146); with improved farming technologies they also were put to new uses. Plows and carts were introduced into Italy in the late fourth millennium BC (Heyd 2013). By the mid-third millennium $\mathrm{BC}$, animal traction must have been sufficiently common to instigate far-reaching changes in agricultural practices. Heavy alluvial soils in the Arno plain (and presumably elsewhere) were first cultivated with wooden plows of the kind unearthed at Lavagnone near Lake Garda, dating to 2048-2010 cal. BC (De Marinis 2000, p. 196; Perini 1983). Bulk produce was now carried back to villages in wheeled vehicles running on the earliest purpose-built roads (Laforgia and Boenzi 2011; Saccoccio et al. 2013). By the same time domestic horses, first documented in the late fourth millennium BC, were employed for traction as much as oxen (e.g., at Querciola; Sarti 1997). Purely functionalist explanations, however, would miss the point that the new technologies and domestic animals had to be socialized before they could be integrated into the productive economy. Ritual provided a range of concepts and practices to ease the introduction of the novel and the strange, and to turn the dangerous into the tame. In Valcamonica (central Alps), plows and carts were added at this time to the rich symbolic repertoire of the local rock art (Casini 1994; Casini and Fossati 2013). At Saint-Martin-de-Corléans, a megalithic site in the western Alps, human teeth were sown into plowed furrows as part of a foundation rite echoed, many miles eastward and many centuries later, by the Argonauts' myth (Mezzena 1998). At Le Cerquete-Fianello (Rome), a domestic horse was skinned, defleshed, dismembered, and eventually buried in an elaborate ritual performance dictating use of a metal blade (Curci and Tagliacozzo 1994, 2002).

Such a broad suite of momentous, interrelated changes is traditionally ascribed to the "secondary products revolution." The concept was introduced by Sherratt (1981, 1983) to explain the dramatic changes in subsistence practices and settlement patterns that swept across Europe at this time. The model's success lies in its ability to provide a coherent socioeconomic explanation for the changing archaeological record. For example, milk boilers becoming more numerous from the late Neolithic indicates growing reliance on dairy products. Likewise, changes in spinning and weaving equipment signify a generalized shift from linen to wool, enabled by new breeds of woolly sheep from the Near East. Animal traction is another key innovation thought to date to this time, as well as the wheel; these, too, were part of the revolutionary material package made available to European society at this time (Broodbank 2013; Whittle 1996). There is no denying that this tangle of innovations and intensifications brought about major transformations in the prehistoric economy. Yet one wonders if this was the game changer that it frequently is assumed to be.

Recent research has shown that, in central Italy as much as farther afield, the Chalcolithic secondary products revolution was neither Chalcolithic nor a revolution 
(Greenfield 2010). Firstly, the new economic regime developed gradually out of a spectrum of well-established Neolithic subsistence practices, and the change was cumulative rather than sudden. Secondly, bimodal butchery curves of sheep/goat and cattle (e.g., at Conelle, Le Cerquete-Fianello, and Casale del Dolce; Bistolfi and Muntoni 2000; Cazzella and Moscoloni 1999; Manfredini 2002) suggest that domestic animals continued to be valued for their meat as much as their milk, wool, and traction power. Thirdly, hunting made an unexpected comeback at a host of upland sites such as Conelle and Ortucchio (Wilkens 2000). Strong selective preference for red deer, a species depicted at multiple ritual locales throughout the peninsula (e.g., Grotta dei Cervi; Graziosi 1996), suggests that hunting was not always a mundane subsistence task but a symbolically laden activity, possibly undertaken during male initiation rites (Dolfini 2017; Whitehouse 1992a). However, the presence of different kinds of quarry (e.g., roe deer and wild boar) at lowland sites reminds us that ritual interpretations may not suit all contexts (Cocchi Genick 2009, p. 175). Whatever the correct reading in specific instances, the overall evidence indicates a staggered move toward diversified subsistence strategies rather than a blanket shift toward specialized pastoral economy. Taken together, the new data suggest that central Italian communities relied on a spectrum of economic resources not greatly dissimilar from those available in other regions of Europe. This view is different enough from previous interpretations focusing on the pastoral economy to warrant future research into changes in human mobility during 4500-2200 BC, how subsistence strategies were adapted to local environmental conditions, and what context-specific cultural responses did the new technologies and domesticates elicit in increasingly fragmented Copper Age society.

\section{Connectivity and Exchange}

Investigations of long-distance exchange in Neolithic Europe and the Mediterranean have overwhelmingly focused on three well-traceable materials: the spiky shells of Spondylus gaederopus, an oyster fished in the shallow waters of the Aegean and Adriatic Seas; igneous and metamorphic "greenstones" (mainly eclogite, omphacitite, and jadeitite) from high-altitude outcrops in the western Alps and northern Apennines; and obsidian, a black volcanic glass found at several island sources in the eastern and central Mediterranean (Robb and Farr 2005). Whereas the Spondylus and greenstone exchange networks largely bypassed the central Italian peninsula, the region was drawn into the sprawling web of the prehistoric obsidian trade.

Obsidian was used in the Neolithic for the manufacture of razor-sharp flakes and bladelets. Long-standing archaeological interest in this material is motivated by its traceability to four central Mediterranean island sources: Monte Arci in Sardinia, Lipari in the Aeolian archipelago, Palmarola off the coast of Latium, and remote Pantelleria in the Strait of Sicily. Chemical fingerprinting of obsidian from these sources (and from individual quarries at Lipari and Monte Arci) has enabled detailed reconstructions of the circulation patterns of this sought-after material (Ammerman 1985; Pessina and Radi 2005; Tykot 1998, 2017; Tykot and Ammerman 1997). 
In the sixth millennium $\mathrm{BC}$, roughed-out blocks and prepared cores from each source were moved to adjacent coastal sites, where they were reworked into preformed blanks and tools that were disseminated to a much wider area via combined maritime and overland exchange. Sicily, parts of southern Italy, and Malta obtained obsidian from the Lipari source. Western Sicily, coastal Tunisia, and Malta were drawn into the smaller exchange network of obsidian from Pantelleria. In the south-central peninsula up to the western and, to a lesser degree, eastern Adriatic shores, the obsidian came from Palmarola. The jet-black obsidian from Monte Arci was exchanged to Sardinia, Corsica, and large swathes of northcentral Italy (Fig. 4). Distribution changed in the fifth millennium BC, when Sardinian and Lipari obsidian was exchanged farther and deeper into their respective circulation zones. By the end of the millennium, Lipari obsidian circulated all over the entire central Mediterranean from North Africa to the Alps, with obsidian from the other sources more restricted to increasingly self-contained spheres of exchange. This is especially true for Palmarola and Pantelleria obsidian, whose

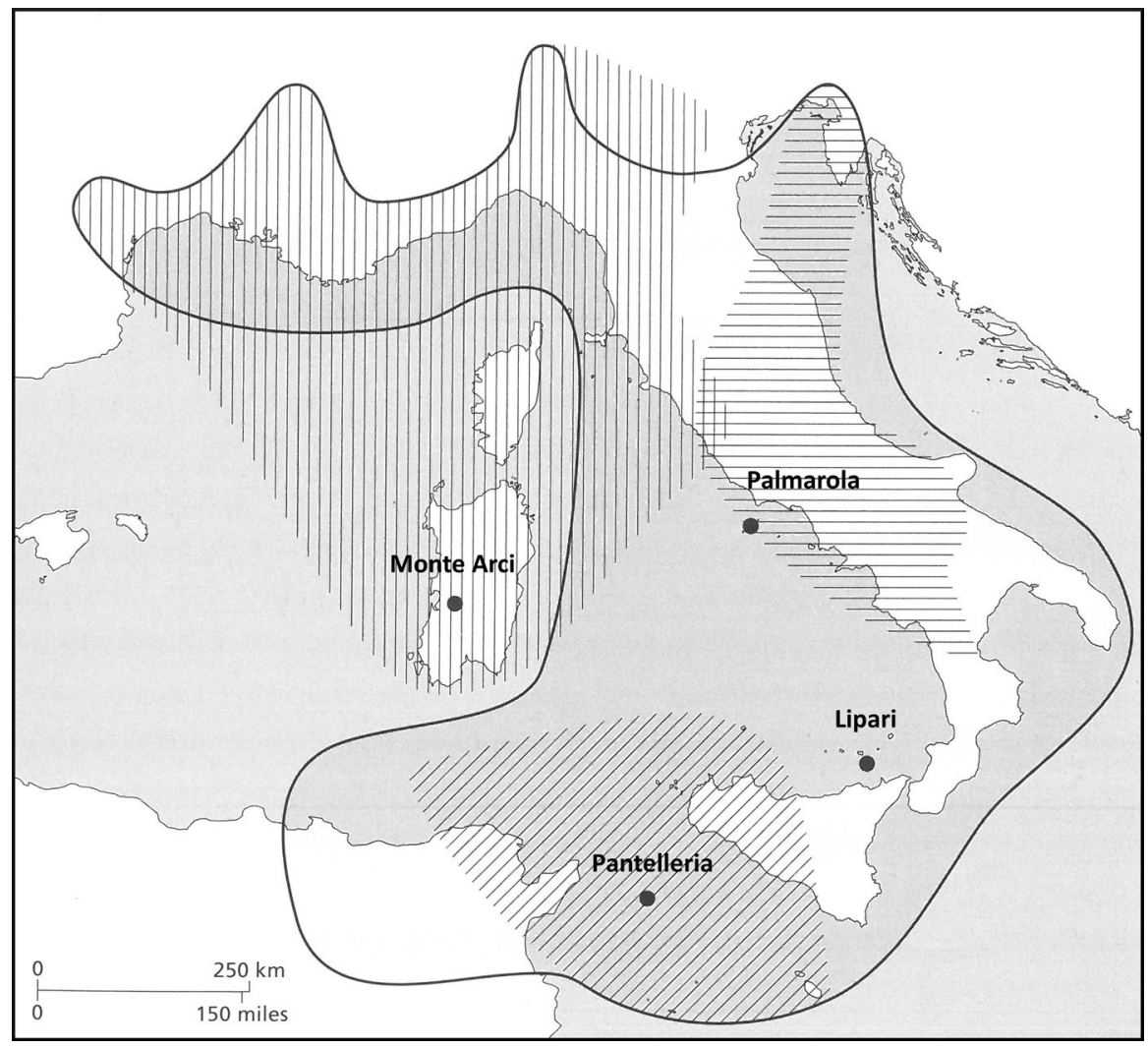

Fig. 4 Dispersal pattern of central Mediterranean obsidian, aggregated over time. By the turn of the fourth millennium BC, the exchange network of Lipari obsidian had grown to encompass most of the region at the expense of Monte Arci, Palmarola, and Pantelleria sources (modified after Broodbank 2013) 
visual and mechanical properties could not compete with the shiny, eminently workable obsidian from the Lipari quarries (Pessina and Radi 2005; Robb and Farr 2005).

Targeted research has clarified the mechanisms of obsidian production and exchange. Evidence from coastal sites in Calabria, where Lipari obsidian makes up over $90 \%$ of the stone toolkit, suggests that people in this "interaction zone" accessed the source directly through seasonal maritime expeditions (Robb and Farr 2005). Farther away, however, the amount of Lipari obsidian progressively decreases to $10-30 \%$ of lithic assemblages. Prevalent coastal distribution patterns suggest that seagoing canoes shuttling back and forth from the direct procurement area were used to supply this "secondary contact zone." From there, the tools circulated down the line, mainly via terrestrial routes. Yet not all tools were traded in this manner. Obsidian-rich hotspots located hundreds of miles away from the quarries indicate that certain communities had preferential access to the material and, in turn, acted as regional brokers in their redistribution (Ammerman 2003; Ammerman and Polglase 1993; Pessina and Radi 2005). Furthermore, alternative procurement systems often coexisted side by side in the same area; in Late Neolithic Abruzzo, for example, Lipari obsidian clustered by the coastline, while Palmarola obsidian mostly reached inland communities. It is presumed that the latter moved over land from the Tyrrhenian Sea through the river valleys and mountain passes of southern Latium (Pessina and Tiné 2008, p. 239).

As interest has largely focused on the spatial and temporal dynamics of obsidian exchange, relatively little has been said apropos the social mechanisms underpinning it. It is frequently assumed that the prehistoric residents of Lipari must have controlled the quarries (e.g., Malone 1986 cited in Skeates 2013, p. 16). As proceeds from the "trade" soared during the fifth millennium BC, so did the risks of unfriendly visits from overseas. To fend them off, the bulk of the populace would have moved to the naturally defended Acropolis site, where, unperturbed, they continued to reap the benefits of an increasingly profitable business. Less modernist explanations have been proposed of late. Noting that trade in tribal societies is often conducted for the sake of the social relations created through it rather than for the mere procurement of commodities, Robb (2007) posited that the communities located in the interaction zone sought Lipari obsidian through seasonal visits. In his view, both Lipari dwellers and visitors engaged in cooperative quarrying, core preparation, and ostentatiously skilled knapping at coastal aggregation sites such as Contrada Diana. Feasting would have eased social interactions between visitors and locals; this is hinted at by the open-air hearths and grinding stones unearthed at Contrada Diana.

With so much research focused on obsidian, other materials and objects have received less attention. As Broodbank (2013, p. 229) perceptively noted, most materials sought by late Neolithic communities were sourced locally; the clay and temper used for domestic pottery are a case in point (Forte and Medeghini 2017). Other materials were displaced over 100-200 km, either because they were not available in the nearby landscape or because of the social value added by exchange. This is the case with high-quality flint from the Monti Lessini and the Gargano peninsula, basalts from northeast Sicily, diorite from Calabria, and, anticipating later trends, 
red jasper and steatite from Liguria and Tuscany (Barfield 1999; Leighton and Dixon 1992; Pessina and Tiné 2008).

Two intertwined phenomena took place in the early fourth millennium BC: the crash of long-distance greenstone and obsidian exchange and, at the same time, a growing interest in different workable materials including, in central Italy, red jasper and steatite. Jasper is a silica-rich stone often containing high amounts of iron, hence its distinctive blood-red color; it is found in the ophiolithic complexes of Liguria and Tuscany, worked since the Paleolithic. It is only in the Copper Age, however, that demand for this material grew exponentially and quarrying reached levels unknown before, or since. At a Copper Age quarry in Valle Lagorara (Campana and Maggi 2002), jasper was extracted using diorite and basalt hammerstones, knapped on site into oval pressure-flaked blanks, and subsequently exchanged down the line. At domestic sites, the blanks were turned into bifacial barbed-and-tanged arrowheads and small daggers, presumably intended for hunting and warfare.

Steatite, or soapstone, has a high talc content that makes it an excellent carving material. Like jasper, it crops up in the ophiolithic complexes of Liguria and Tuscany, where it is found in colors varying from off white to green. Though utilized since the Early Neolithic, this stone became increasingly popular in the fourth millennium BC (Pessina and Tiné 2008). A Copper Age steatite workshop has been excavated at Pianaccia di Suvero in eastern Liguria. It is presently unclear if this was purely a workshop site, as the excavators believe (and is the case with the jasper quarries-cum-workshops from the region; Campana and Maggi 2002; Campana et al. 1998), or if the stone was worked by a settled village community. Whichever the case, excavations have ascertained that the soapstone was brought to the site from a yet unidentified quarry and was expertly turned into round beads, small pendants, and, in the mid/late third millennium BC, Beaker-style V-bored conical buttons. The stone was worked following standardized operational sequences. The blocks and nodules from the quarry were first roughed out, then perforated, and finally carved into shape, smoothed out, and polished. Lithic tools were utilized in the first and second step of the sequence, while metal blades were preferentially employed in the third (Gernone 1998). Although steatite circulation patterns have not been analyzed in detail, it appears that, as with jasper, artifacts made from this stone were exchanged over distances of 100-200 km from the production areas. Chert was extracted and worked in a similar manner at numerous sites along the eastern edge of the Apennines, as well as farther south (Skeates 2003; Tarantini and Galiberti 2011).

Obsidian continued to be in demand in the Copper Age, but only close to the sources. In the Aeolian archipelago and Sardinia, in particular, obsidian remained the principal knapping stone until the late Bronze Age. Farther afield, however, procurement of this material declined rapidly. Comparison of two residential sites in Rome's hinterland show this decline: Lipari and Palmarola obsidian make up 42\% of the lithic assemblage at Late Neolithic Quadrato di Torre Spaccata (Anzidei and Carboni 1995), while at Copper Age Le Cerquete-Fianello, only three bladelets were recovered during extensive investigations (Manfredini 2002). This trend can be followed throughout the entire central Mediterranean region and is compounded by the equally rapid shrinking of greenstone exchange networks after 4000 BC (Cazzella 
1994; Melis 2009; Vaquer 2006). As with the island sources of obsidian, high-altitude Alpine quarries continued to be visited in the Final Neolithic and Copper Age, but axe heads and other objects made from greenstone were now displaced within a $200 \mathrm{~km}$ radius. As their Europe-wide exchange network fizzled out, greenstone objects metamorphosed from value-laden symbolic artifacts into humble workaday tools (Pétrequin et al. 2008, p. 272; see Malta for a significant exception: Skeates 1995b). Obsidian likely underwent a similar transmutation in its social significance, perhaps outcompeted by a material of unprecedented surface shine: metal.

\section{The Emergence of Metallurgy}

A large band of Tyrrhenian Italy stretching from eastern Liguria to northern Latium (also extending into the northern Apennines) is home to some of the richest oremineral deposits in Europe. From late fifth to late third millennia BC, copper, silver, and antimony were extracted from theses ores. Copper is found as a native metal and also was extracted from iron-copper sulfides (e.g., chalcopyrite, bornite), sulfosalts (e.g., tetrahedrite and tennantite), and oxides/carbonates (e.g., malachite and azurite). Silver was reduced from argentiferous "dry ores" (e.g., cerargyte and fahlores), lead compounds (e.g., galena and cerussite), and perhaps sourced as native silver. Antimony was extracted from a sulfidic ore called stibnite. Cassiterite (tinstone) deposits are known in Tuscany, but it is unclear if they were ever exploited in prehistoric times (Giardino 1998, pp. 134-135). Similarly, it is doubtful if the arsenic and iron-arsenic sulfides (e.g., arsenopyrite, orpiment, and realgar) that occur in small concentrations throughout the region were mined at this time to make arsenical copper. Several scholars suggest that this early alloy may have been obtained from the smelting of arsenic-rich copper minerals such as tennantite (Craddock 1995, p. 289; Killick 2014), which fits the central Italian evidence rather well (Dolfini 2014). Important nonmetallic minerals also are present in the region, including cinnabar, a blood-red mercury compound sought in prehistory as a pigment. Ore deposits do not extend east of the Apennines or south of the Tiber Valley due to the different geological history of these areas (Carobbi and Rodolico 1976; Cavinato 1964; Lotti 1910).

After a long period of stasis in the 1980s and 1990s, interest in the beginnings of copper mining, smelting, and working in central Italy has surged recently (Dolfini 2013a). The new research agenda has focused on two long-standing problems: the chronology of early metalworking and objects, and early copper-alloy technology and exchange. Dramatic developments in both subjects have disproved deeply held views and misconceptions, leading to important new insights into the evolution, transmission, and social significance of early metallurgy, as outlined below.

\section{The Chronology of Early Metalworking in Central Italy}

For most of the 20th century, the origins of central Italian metallurgy were framed by two competing metanarratives: diffusion and independent development (Roberts 
et al. 2009). Following the migrationist paradigm prevailing at the time, early culture historians maintained that newcomers from either the eastern Mediterranean or the Balkans introduced copper technology into Italy. These scholars saw the Chalcolithic migrants not as peaceful settlers but as warring nomadic shepherds who conquered the local Neolithic farmers thanks to their superior metal weapons (Laviosa Zambotti 1943; Peet 1909; Puglisi 1959; Trump 1966). Barker (1971, 1981) and Renfrew and Whitehouse (1974), among others, rebutted early diffusionist models. They stressed the local character of early Italian metalworking, whose impressive florescence they credited to a combination of local advances and information exchange with areas of earlier metal production. In the same years, fine-grained chronologies were first put forward to date early metal axe heads, daggers, and halberds based on empirically constructed typologies. These, however, were not underpinned by formalized seriation sequences or radiocarbon (Bianco Peroni 1994; Carancini 1993; Peroni 1971).

Due to the speculative nature of the typological work, the evidence was pulled in two opposite directions. On the one hand, several prehistorians divided early central Italian metals into two clear-cut horizons marked by specific object types. They controversially assigned the first horizon to the advanced Copper Age (c. 3000-2200 BC) and the second to the initial Early Bronze Age (c. 2200-2000 BC) (Carancini 1993, 2001; Peroni 1996). To account for the objects occasionally found at earlier sites, they posited that a protracted phase with "incipient metallurgy," fed by occasional imports from the northern Alps and the Balkans, preceded the first metallurgical horizon (Carancini 2001, p. 236). A similar, if slightly backdated chronology was later proposed by De Marinis (2006); this was widely accepted until recently (Strahm 2007; Strahm and Hauptmann 2009).

On the other hand, a minority group of researchers claimed that the origins of Italian metallurgy were rooted in local Neolithic practices. Barfield $(1966,1996)$, in particular, assigned certain archaic-looking axe heads to the Middle Neolithic, while Skeates (1993) and Pearce (2007) took a more cautious approach, arguing for the (mainly) Late Neolithic origins of Italian metallurgy. Because few radiocarbon dates were available at the time, the problem was largely left unresolved, and a consensus of sorts coalesced around two notions. The first postulated that metallurgical knowledge was introduced into central Italy significantly later than in the northern Alps and Sardinia. The second maintained that early metals from the region could typologically, and perhaps technologically, be divided into two clear-cut horizons; first, the Middle/Late Copper Age and, second, the Late Copper Age and Early Bronze Age. Italy was thus consigned to the limbo of areas that, in accounts of the origins of world metallurgy, were rarely mentioned due to their perceived role as centers of secondary development (Dolfini 2013b).

Recent research has dramatically disproved both notions and has clarified the overall developmental sequence of early metal technology in the region. Radiocarbon dating of metal-rich chamber graves and funerary caves provided the most striking results (Anzidei et al. 2011a, 2012; Dolfini 2010; Manfredini et al. 2009; Petitti et al. 2011). These showed that the chronology built by the typologists of old was at odds with the historical realities of early Italian metal making. Objects that were previously thought to be Late Copper Age turned out to be Final Neolithic, 
and objects once dated to the Early Bronze Age were newly assigned to the Early Copper Age. In a few instances, whole classes of artifacts were shown to be 1000 years older than previously believed, and perhaps older still. While many radiocarbon dates cluster in the Early Copper Age, none fall squarely in the Early Bronze Age, proving that central Italian metallurgy is neither late nor necessarily derivative. The new chronology has, in fact, aligned the onset of metallurgy in this region with the northern Alps and Sardinia, highlighting previously unsuspected instances of rapid knowledge exchange over remarkable distances (Dolfini 2013b). Radiocarbon has also shown that ternary copper-arsenic-antimony alloys, previously thought to reflect a late technological horizon (De Marinis 2006), were mastered from the mid-fourth millennium BC alongside pure and arsenical copper. This demonstrates the sophistication reached by central Italian smiths at the dawn of metal production.

Overall, the new research has revealed that copper, silver, and antimony metallurgy began in earnest in the Early Copper Age (3600-3300 BC), following sustained experimentation (limited to copper) in the Late Neolithic (4500?-3800 BC) and Final Neolithic intensification (3800-3600 BC). Metallurgical knowledge was likely introduced from the western Balkans via the eastern Alps and northern Italy (Dolfini 2013b). Awls and axe heads were the first objects made from copper in central Italy; they overall date to the Late Neolithic and not the Middle Neolithic as was once proposed (Dolfini 2013c). Smelting slags found at Orti Bottagone, an early fourth millennium BC site in Tuscany, suggests that objects were manufactured in the region using locally sourced copper (Artioli et al. 2007; Fedeli and Galiberti 2016, p. 147), disproving earlier suggestions that Neolithic metallurgy relied on imports from farther away. Possible slags and crucibles from Botteghino (northern Italy) may push the onset of extractive metallurgy south of the Alps farther back in time, pending the necessary scientific analysis (Mazzieri and Dal Santo 2007).

Metal production surged in the mid-fourth millennium BC. By this time, central Italian smiths had mastered all steps of the chaîne opératoire of copper extraction, enabling them to fashion several types of axe heads, daggers, and halberds using pure and arsenical copper (Dolfini 2010, 2013b, 2014). An important component of this technological intensification was the application of extractive metallurgy to ores other than copper, including silver and antimony. This is one of the earliest instances of antimony extraction in world history. This metal was likely discovered independently in Tuscany (where stibnite ores abound) through a trial-and-error process involving the adaptation of copper-smelting technology to a different ore. Silver and antimony were used to cast several types of ornamental beads. Importantly, the midfourth millennium technological outburst was accompanied by crucial developments in the signification of metals, which first entered the funerary domain as markers of gender, age, and perhaps status (see below).

Metal production seemingly varied little until the mid-third millennium BC. The earliest objects containing appreciable amounts of tin-a ring from Poggio Olivastro and a bead from Prima Ciappa-date to this time (Bulgarelli and Giumlia-Mair 2008; Campana et al. 1996). Arsenic and other impurities revealed by chemical analysis suggest that these objects were probably obtained from smelted copper-tin ores (e.g., stannite) rather than by adding metallic tin to the copper melt. This would be in line with Copper Age metallurgical practices in the region, featuring ore selection 
rather than alloying to obtain the desired metallic substances. Moreover, these isolated objects predate the development of tin-bronze technology in Western Europe from 2300/2200 BC (Pare 2000).

It is presently unclear when exactly tin-bronze technology was introduced into central Italy and where the tin came from. In their study of early metal flows in the Alpine region, Perucchetti et al. (2015) showed that tin appeared in the western Alps earlier than farther east, perhaps coming from southwest Britain around 2200-2000 BC. According to De Marinis (2006), during the initial Early Bronze Age, central Italian smiths still relied on arsenical and arsenical/antimonial alloys, with tinbronze technology emerging after $2000 \mathrm{BC}$. He argues that the two technologies then coexisted for a while, until tin bronzes became exclusive from 1800/1700 BC (see also Pare 2000; Spindler 1971). Although the technological sequence described by De Marinis seems correct overall, it is nonetheless grounded in an outdated chronological framework that assigns many Copper Age metals to the Early Bronze Age (see above). Considering the overall backdating of early metalwork discussed above, it is likely that the entire sequence should be shifted back some two centuries, aligning central Italy with the western Alps (Dolfini 2010). Currently, this is an open question that should be targeted in future investigations.

\section{Early Copper Technology and Metalwork Exchange}

Recent interdisciplinary research has clarified aspects of the chaine opératoire of copper extraction, working, and exchange. At two copper mines in Liguria-Libiola and Monte Loreto-chalcopyrite (presumably supplemented by now-depleted surface deposits of copper oxides/carbonates) was extracted through underground working and tunneling, aided by fire to loosen the rock face. The copper minerals were crushed outside the mine with basalt hammerstones, then hand sorted to separate the ore from the gangue (but not smelted on site). Once a vein was exhausted, miners backfilled the gallery, perhaps urged by cultural preoccupations. Radiocarbon dating has pinpointed the inception of ore mining at both Libiola and Monte Loreto to the mid-fourth millennium BC (Maggi and Pearce, 2005; Pearce, 2007, pp. 62-70); this dovetails with the metallurgical surge discussed above. Further evidence of early ore-mineral extraction is present at Buca di Spaccasasso and Poggio Malinverno; the former is a third millennium BC cinnabar quarry where burial was also performed, while the latter is presently undated (Cavanna and Pellegrini 2007; Giardino and Steiniger 2011; Volante 2014). If considered with the historic evidence (e.g., Aranguren and Sozzi 2006; Cocchi Genick and Grifoni Cremonesi 1989; Mochi 1915), these discoveries greatly strengthen the case for the antiquity and scale of prehistoric mining in west-central Italy.

New excavations and scientific analysis have also increased our knowledge of early smelting technology. Excavations at San Carlo-Cava Solvay, a now-destroyed domestic site in Tuscany (Fedeli and Galiberti 2016), brought to light several firedclay platforms partly surrounded by curvilineal limestone walls. These are similar to early smelting installations in southern France and the eastern Alps (Ambert et al. 2005, 2013; Perini 1992). The analysis of slags and crucibles from the site 
has revealed that copper and iron-copper compounds, some containing appreciable amounts of arsenic and zinc, were co-smelted on the platforms using a surprisingly efficient reduction technology. The smelting charges variously comprised chalcopyrite, sulfosalts (e.g., tetrahedrite and tennantite), and copper oxides/carbonates (e.g., cuprite); these were reduced in crucibles heated from above by blowpipes and/or bellows (Artioli et al. 2016). The process led to the formation of well-reacted silica slags lacking the unreacted ore fragments and entrapped copper droplets typical of early metallurgical residues (Bourgarit 2007). This is all the more remarkable considering the late fourth millennium chronology of San Carlo-Cava Solvay, which makes it one of the earliest metallurgical sites in Europe. Future research will clarify if this technological leap is unique to this settlement, or whether it is shared by other early smelting sites in the region.

Although the smelting evidence, and most metalwork, cluster near the ore deposits of west-central Italy, alleged casting and working residues have been found all over the region, including in resource-starved Marche and Abruzzo (Dolfini 2014). Many of these residues, however, are difficult to assess due to the lack of targeted scientific analysis. Some look like genuine casting scraps (e.g., at Conelle; Palmieri and Cazzella 1999, fig. 48.4); others, however, might be highly fragmented and eroded objects (e.g., at Querciola and Maddalena di Muccia; Manfredini et al. 2005b; Sarti 1997). Whatever the case, metal waste of this kind offers much-needed clues that copper circulated well beyond the extraction zones of Tuscany and Liguria. Multiple strands of evidence support this reading. For example, bone artifacts from Conelle, a Copper Age site in Marche, were carved into shape using metal tools (Cristiani and Alhaique 2005); yet these tools are nowhere to be found, except for a single nondescript knife (Palmieri and Cazzella 1999, fig. 48.3). More generally, metal objects are extremely rare in east-central Italy including at burial sites that, west of the Apennines, teem with copper-alloy weapons. A major visibility bias is in operation here, probably caused by widespread copper recycling as well as divergent social behaviors that dictated the placing of metals with the dead in the western and eastern peninsula (Lemorini 2012; Pearce 2009).

Recent applications of lead isotope analysis - a not uncontroversial provenancing method (Pernicka 2014; Radivojević et al. 2019)— have provided yet more inklings as to the wide circulation of early metals and how visibility biases may obscure it. The technique was applied to the axe head carried by the Iceman, a late fourth millennium BC mummy from the eastern Alps, and a coeval (and typologically similar) implement from Zug-Riedmatt, Switzerland. The analyses revealed that both objects were made from copper likely sourced in the Colline Metallifere ("Ore Mountains"), a conspicuous ore body in Tuscany (Artioli et al. 2017; Gross et al. 2017). Orti Bottagone and San Carlo-Cava Solvay lie in this area. Recent lead isotope analysis of 20 axe heads and daggers from central Italy (Dolfini et al., in press) shows that while most objects were fashioned from metal from Tuscany, others were made from copper whose isotopic signal points to the western Alps and southern France. Occasionally, metals came from farther away, such as an axe head from Rome's hinterland, whose Levantine shape and Cycladic isotopic fingerprint suggest an eastern Mediterranean origin (Anzidei et al. 2018). Considering the abundance of cupriferous ores in Tuscany, such instances of "bringing coals to Newcastle" open 
up unexpected scenarios regarding early metalwork circulation, which only future research can elucidate.

The objects themselves provide a great deal of information concerning early metal technology. Giardino (2009-2012) observed patterns of wrinkles stretching along the vertical axis of two late Neolithic axe heads, as well as, in one specimen, congealed copper droplets (caused by the mold cracking under thermal stress) running downward from the butt (Fig. 5). Both features, which he reproduced experimentally, demonstrate use of bivalve molds at the very inception of copper metallurgy. The wear analysis of 48 Copper Age axe heads, daggers, and halberds further suggests early use of bivalve molds in the region (Dolfini 2011; Iaia and Dolfini, in press). The research highlights several features that are incompatible with onepiece molding including, in axe heads, hollowed-out faces and blowholes (on both sides) caused by trapped gases; v-shaped shrinkages on axe butts due to insufficient quantities of metal being poured in; and, in bladed implements, symmetrical

Fig. 5 Late Neolithic copperalloy axe head from Rapolano, Siena. Congealed droplets running down from the butt suggest that this object was cast in a bivalve mold, indicating knowledge of two-piece casting since the very beginning of metal production (photograph reproduced by courtesy of the Museo delle Civiltà 'L. Pigorini,' Rome)

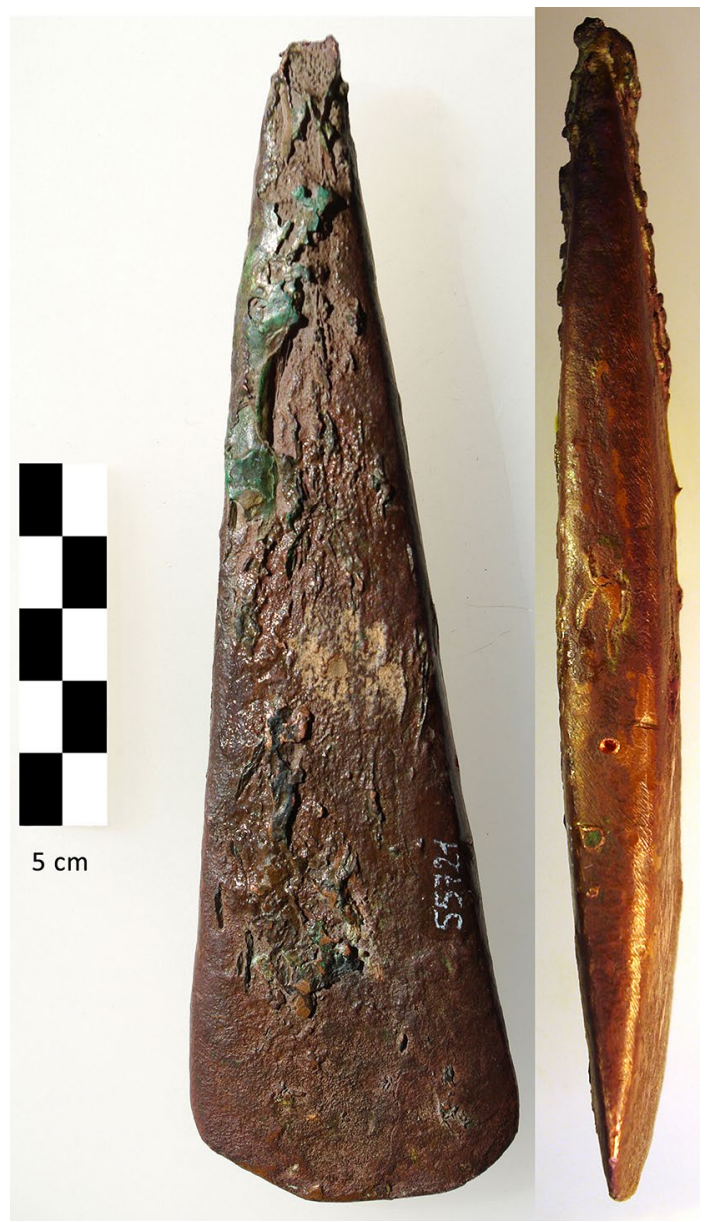


midribs. Objects cast in monovalve molds (as suggested by marked asymmetries in object profiles) are present in the sample but not in great numbers. This goes against received wisdom postulating that "more advanced" bivalve molds followed early experimentation with "simpler" monovalve ones. Emphatically, the data show that this is not the case, for two-piece and one-piece molds were used side by side in early central Italy, the former not just predating but also greatly outnumbering the latter (Dolfini 2011; Iaia and Dolfini, in press). Similar patterns are found in other areas of early Europe (Crellin 2018; Kienlin 2010; Kuijpers 2018).

Wear analysis has shown, moreover, that evidence of shaping and smithing may be discerned on axe heads in the form of thickened or flattened margins, raised flanges, and bevels between axe bodies and cutting edges. Hammer marks also were observed on the cutting edges of certain axes, suggesting work-hardening prior to use. Work-hardening poses a much-debated problem in early European metallurgy, one that intersects notions of technological evolution, skill, and knowledge transfer. It is generally presumed that prehistoric copper-alloy tools were hardened to lengthen their use life and increase their performance. While the procedure was routinely deployed in the Bronze Age, it is presently unclear when, and how consistently, it was performed prior to that. Scientific analyses suggest that, in the northern Alps, early axe heads were frequently hardened, while in the southern Alps Copper Age smiths were either unaware or mostly uninterested in enhancing tool functionality through hammering (Artioli 2007; Kienlin 2008, 2010). Recently, Kuijpers (2018) has argued that the problem needs retheorizing, for performance is a cultural concept that stems from contingent factors, including alloy composition and "the standard of the time" or the technological baseline to which smiths and users refer in judging the quality of a tool. While the problem cannot be solved with regard to central Italian metals pending further analyses, the coexistence of monovalve and bivalve molds disprove long-standing ideas of linear technological change, which might apply to work-hardening, too. The new research shows that different communities of practice adapted technical knowledge to the specific social and material conditions in which they operated, and that an array of factors including the skill and experience of the coppersmith contributed to determining the quality of the finished objects.

\section{Funerary Practices and Ideas of the Body}

For much of the Italian Neolithic, the village acted as a cultural pivot for the daily enactment of social relations and the reproduction of individual and collective identity. Burial was mostly performed in domestic contexts: under house floors, in pits and trenches scattered across settlement sites, and, significantly, in ditches marking the symbolic boundaries of village communities (Robb 2002, 2007). Things began to change in the fifth millennium $\mathrm{BC}$, when the dead were first interred at distinct locales within the village, signifying separation from daily life. At the same time, mortuary rites grew more formalized and featured increasingly elaborate bone manipulation, fragmentation, and reburial customs (Dolfini 2015). 
The beginning of this long-term trajectory can be traced back to the advanced Middle Neolithic, when, in southern Italy, discrete burial grounds were first established at the edge of inhabited or recently abandoned villages (Conati Barbaro 2007-2008). The trend toward burial segregation gained momentum in the late Neolithic, as seen for example in the extramural cemeteries of Masseria Bellavista, Scoglio del Tonno, and Cala Tramontana (Palma di Cesnola 1967; Quagliati 1906). These sites display frequent reorganized burials and standardized grave goods, anticipating widespread Copper Age features. As a further intimation of things to come, hypogeal burial chambers appeared at this time at Arnesano, Serra d'AltoFondo Gravela, and perhaps Scoglio del Tonno (Manfredini 2001; but see Pessina and Tiné 2008, pp. 289-291, for problems of interpretation).

In central Italy, key evidence for fast-changing ideas of the dead comes from Ripoli (Cremonesi 1965), where the Late Neolithic village featured a discrete burial ground consisting of nine trenches that cut across the inhabited space. The exact layout of these burials is unclear, however, as they were investigated in the early 1900s (Rellini 1934). At least 44 individuals were interred in the Ripoli trenches, varying from one to 14 per feature. Skeates (1995a) maintains that the mourners first placed a body in the grave; they would then leave the grave open to allow the soft tissues to decompose. After some time, they would return to the grave to manipulate the dry bones and carry out funerary feasts whose conspicuous remains characterize many burials at the site. However, Grifoni Cremonesi (2003a, p. 266) pointed out that any reconstruction of the burial process at Ripoli is hampered by the scant evidence available. Alongside open settlements, caves were used in the Late Neolithic for funerary practices, especially in the Apennine uplands. Even at these sites, however, burial and ancestor veneration rituals were progressively moved into the deeper recesses, away from the cave mouths where domestic life concentrated (Skeates 1997b; Whitehouse 1992a). This is most apparent at Grotta dei Piccioni, where inhumation, skull curation, and other ritual performances were carried out in a secluded space at the bottom of the cave (Cremonesi 1976).

The lengthy process of separating the dead from the living ended in the Final Neolithic and Copper Age. Burial was moved out of the domestic space, and cemeteries were created in the landscape as separate and often secluded locales for the performance of funerary rites. At the same time, mortuary practices acquired an increasingly formulaic character, to the point that funerary customs shared recurrent traits over large, if not necessarily bounded areas. Two such customs characterize central Italy in the fourth and third millennia BC: interment in caves, the Vecchiano tradition, and burial in hypogeal chambers (occasionally supplemented by trench and cist tombs), the Rinaldone tradition. The former concentrates along the Tyrrhenian coast and in inner Tuscany and upland Abruzzo, while the latter clusters in southern Tuscany/northern Latium, the lower Tiber Valley, and the Adriatic lowlands. In Rome's hinterland, Rinaldone burials interdigitate with cemeteries in the Gaudo and Laterza styles that characterize the southwestern and southeastern peninsula, respectively. Gaudo burials feature hypogeal chambers similar to Rinaldone's (but the goods and mortuary rites are partly different), while Laterza cemeteries consist of individual trench burials (Anzidei et al. 2011a, b, 2012; Cocchi Genick 2009; Negroni Catacchio 2006). Burial continued to be performed at open 
villages during the Copper Age, but evidence is so scant and indistinctive to give us the impression that this was not a significant countertrend to what was going on in the broader landscape.

Most burial caves are poorly known due to infrequent modern excavations and high rates of looting. It is presumed that, at most places, mortuary rites began with the inhumation of articulated bodies followed by the manipulation and fragmentation of the dry bones. The archaeological outcomes of these processes, whose taphonomy may be exceptionally hard to disentangle, are thick deposits in which large amounts of bone fragments are mingled with potsherds, dismembered necklaces, and stone and metal weapons. Burial caves were used by communities ranging from a single lineage (e.g., Prima Ciappa; Maggi and Formicola 1978) to large coresidential groups (e.g., Grotta San Giuseppe and Grotta del Fontino; Cremonesi 2001; Vigliardi 2002). Radiocarbon shows that many of these sites remained in use for centuries.

The Rinaldone burial tradition is typified by small cemeteries, seldom exceeding 20 graves, organized in clusters of low-ceilinged, subterranean chambers cut in the soft tufa or limestone bedrock. Entrance shafts or short corridors precede the tombs, which normally included a small number of individuals, both articulated and reorganized. Women, men, and children of all age groups were afforded formal burial, although infants and young children are absent or significantly underrepresented at all but a handful of sites. More often than not, articulated bodies were placed, legs flexed, on their left sides regardless of gender, while dismembered remains were carefully arranged along the chamber walls or near the entrance (Fig. 6). However, variation is high both within and between sites, thus suggesting that mortuary behavior was predicated upon an array of context-specific customs and conventions (Dolfini 2006a).

Gender and age were frequently stressed in articulated burials through recurrent sets of goods. Typically, weapons were placed with men, while ornaments such as composite necklaces and pins accompanied women and children. Copper-alloy awls, whose lifetime function and funerary uses are still debated (Pearce 2007, pp. 48-50), were given to all gender and age groups, as were bottles and flasks containing an intoxicating drink akin to mead (Carboni et al. 2015). To some extent, gender and age also were expressed through bodily layout. In Copper Age burials, however, the focus was not on orientation (as in the Neolithic) but on manipulation, or lack thereof, as male skeletons remained articulated more often than those of women and children (Dolfini 2006a, b).

An unprecedented degree of ritual elaboration characterized Copper Age mortuary practices. Evidence from Rinaldone-style chamber graves, albeit not uniform, suggests that the burial process encompassed three main steps: interment of a fleshed (and often furnished) individual, flexed sideways; manipulation of the dry bones, which were removed, partly or totally, from the grave and probably recirculated among the living; and reburial of selected remains (normally skulls and long bones), which were mixed with ancestral bones and stacked along the tomb walls or near the entrance (Table 2). This echoes the tripartite structure of rites of passage discussed by Van Gennep (1909), comprising rites of separation of the dead from the living; rites of liminality marking the transition to their new 


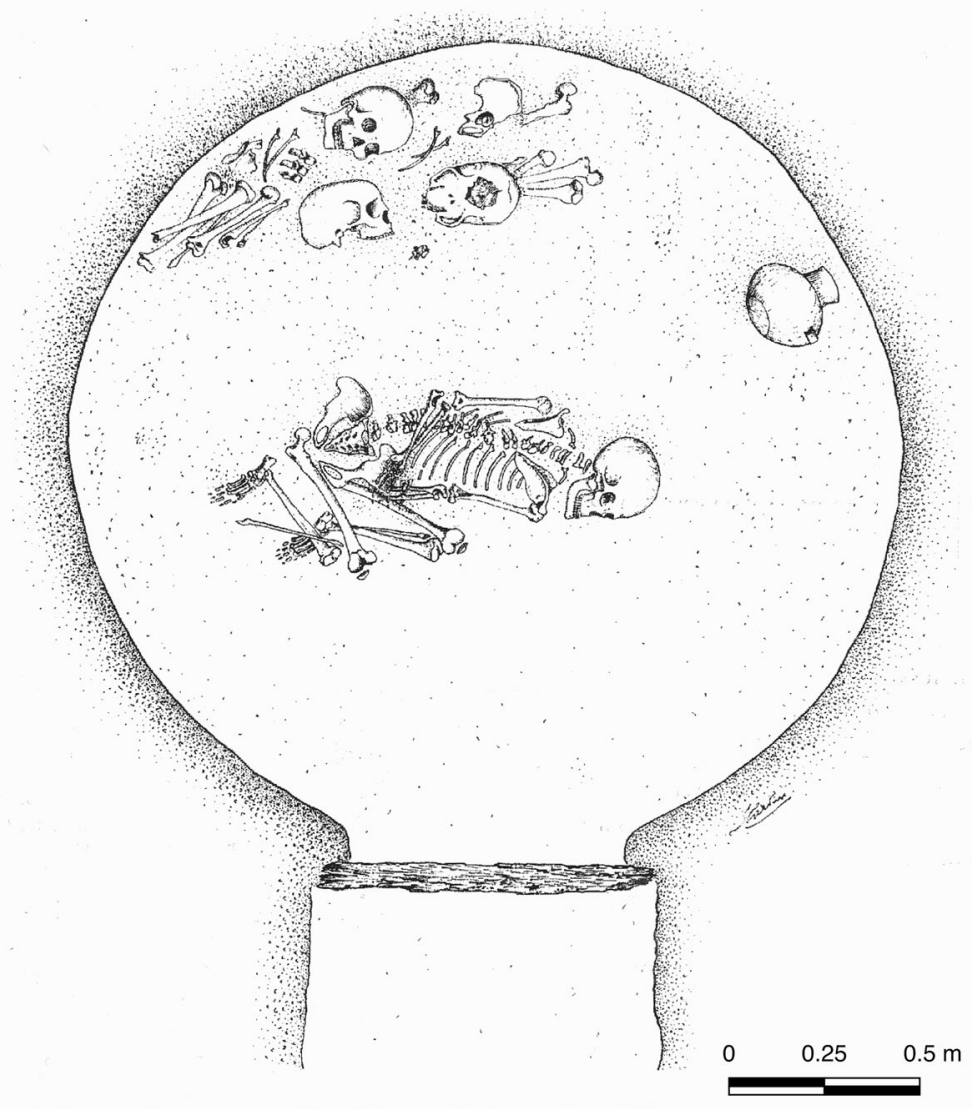

Fig. 6 Articulated burial and dismembered human remains from Ponte San Pietro, tomb 22. The chamber tomb is typical of the Rinaldone burial custom that arose in central Italy during the fourth millennium BC (Miari 1995)

state; and rites of incorporation sanctioning their final integration into the world of the dead. In Copper Age funerals the intermediate step (i.e., Van Gennep's rites of liminality) was especially elaborate. This featured an astonishing variety of bone manipulation practices ranging from the removal of the skull to the complete disarticulation of the skeleton. Objects also were removed from the grave to be circulated and sometimes redeposited with disarticulated burials. This is especially true of the drinking vessel accompanying the deceased. The vessel was broken up as the skeleton was reorganized, and its fragments were presumably distributed among the living along with body parts. Eventually, select potsherds and bones were returned to the grave to mark the end of the burial process and the incorporation of the deceased into the realm of the ancestors. In burial caves, bodily fragmentation took a more extreme form than in chamber tombs, for the 
Table 2 The funerary program deployed in Copper Age chamber tombs entailed three main steps: interment, manipulation, and reburial

\begin{tabular}{|l|l|l|l|}
\hline \multicolumn{2}{|c|}{ INTERMENT } & \multicolumn{1}{c|}{ MANIPULATION } & \multicolumn{1}{c|}{ REBURIAL } \\
\hline \multirow{2}{*}{$\begin{array}{l}\text { Interment of an articulated } \\
\text { body, crouched on the left- } \\
\text { hand or right-hand side }\end{array}$} & $\begin{array}{l}\text { Manipulation or removal of the } \\
\text { skull }\end{array}$ & Reburial of the skull \\
\cline { 2 - 4 } & $\begin{array}{l}\text { Interment of further articulated } \\
\text { bodies }\end{array}$ & $\begin{array}{l}\text { Manipulation or removal of the } \\
\text { upper body; the lower limbs are } \\
\text { left in situ }\end{array}$ & $\begin{array}{l}\text { Reburial of the upper body, } \\
\text { reorganized }\end{array}$ \\
\cline { 2 - 5 } & $\begin{array}{l}\text { Manipulation or removal of skull } \\
\text { and limbs; spine/ribs (and } \\
\text { occasionally feet) are left in situ }\end{array}$ & $\begin{array}{l}\text { Reburial of the entire body, } \\
\text { reorganized }\end{array}$ \\
\hline \multirow{2}{*}{$\begin{array}{l}\text { Occonipulation or removal of the } \\
\text { entire body; tiny bone fragments } \\
\text { are (unintentionally?) left in situ }\end{array}$} & $\begin{array}{l}\text { Reburial of the entire body, } \\
\text { reorganized and mixed with } \\
\text { other bodies }\end{array}$ \\
\hline
\end{tabular}

As in Van Gennep's (1909) cross-cultural examination of rites of passage, the intermediate step (or 'rites of liminality') may be especially elaborate and long lasting (Dolfini 2015)

bones of the dead were systematically broken and mixed with ancestral relics, until no recognizable human form could be discerned in the commingled deposit.

Despite much local variation, the widespread occurrence of this tripartite burial custom suggests that Copper Age mortuary practices aimed to remove the individual identity and lifetime persona of the deceased. This process would have ensured that the newly dead was integrated into a nonindividualized community of the ancestors (Cocchi Genick 2004; Dolfini 2004; Skeates 1995a). As a counterpoint to this prevalent practice, however, certain bodies were left undisturbed in the grave. Significantly, their goods were left beside them, untouched, and their funerary vessels were not broken.

To understand this minority burial custom, we turn to another medium of bodily representation found in central Italy at the time: stelae. Anthropomorphic statuary emerged in many regions of Europe during the fourth and third millennia BC (Robb 2008, 2009), including Lunigiana, a mountainous area straddling present-day Tuscany and Liguria. Lunigiana stelae depict the human body in a formulaic manner. Body features include flexed arms with fingered hands, a horizontal line standing for the shoulders, and nonindividualized faces with straight noses, round faces, and, occasionally, two circles on either side of the head, presumably indicating ears or earrings. The lower body is never engraved. The head was carved into two alternative styles. The Pontevecchio style features short hemispherical heads directly attached to the torso; the Malgrate style presents peculiar crescent-shaped heads joined to the shoulders by carved-out necks (Fig. 7). As the two head designs occur in different areas of Lunigiana, their visual differences might have marked out distinct tribal identities (De Marinis 1995; Maggi 2001).

It appears that the Lunigiana stelae stood aligned in the open landscape, away from habitation or burial sites. They might have been erected along transit routes leading to mountain passes or high-altitude pastures, which gained economic and social relevance in the fourth and third millennia BC (see above). At Pontevecchio, 

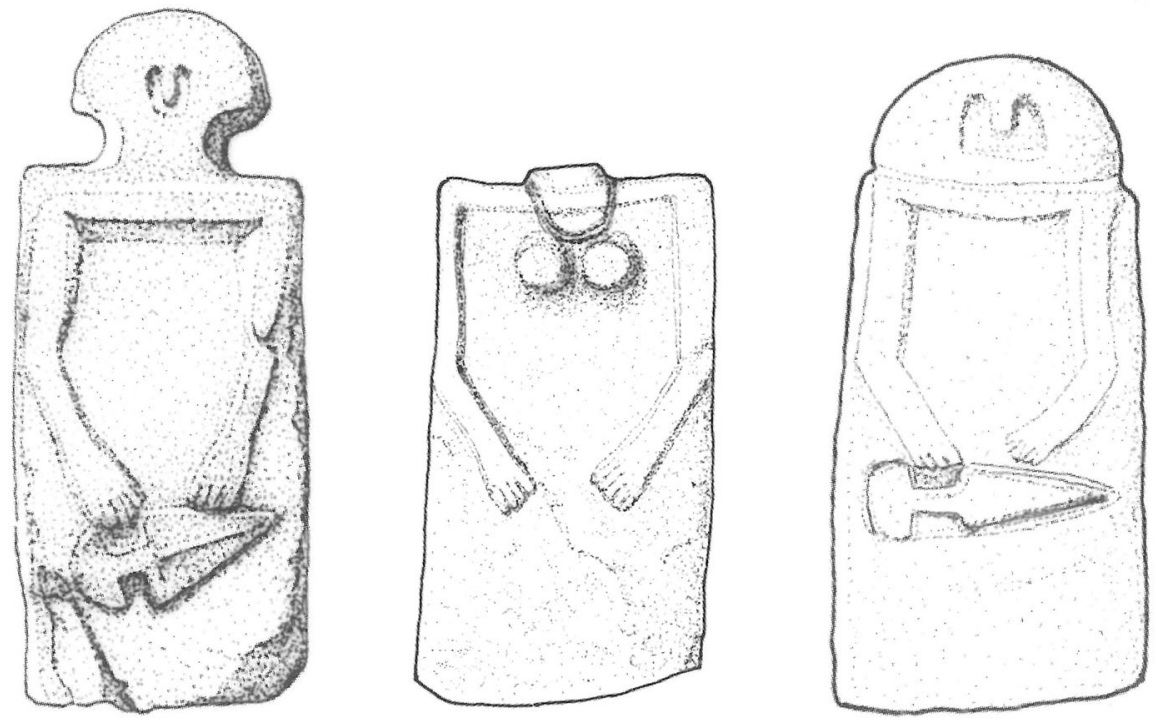

Fig. 7 Selection of Lunigiana stelae: left, Malgrate type, male; center, Malgrate type, female; right, Pontevecchio type, male. Note the gender markers, namely daggers (phallus-like, on the hips) for the males and breasts and necklaces for the females. Approximate height of complete stelae is $120 \mathrm{~cm}$ (modified after Cocchi Genick 2004)

a row of eight stelae were uncovered in the early 20th century (Mazzini 1909), and there are later discoveries from Minucciano (Ambrosi and Mannoni 1972). Alignments of stelae presumably acted as foci for ritual performances. Although no quality contextual data are available for stela sites in Lunigiana, recent findings from Ossimo-Anvoia (south-central Alps) provide much-needed clues to the cultural activities performed at such locales. Ossimo-Anvoia consists of a small mountainside plateau rising $860 \mathrm{~m}$ above sea level. The site was visited for about 1000 years, from the late fourth to the late third millennium $\mathrm{BC}$, for ritual performances focusing on the erection, modification, and removal of anthropomorphic stelae and monoliths. Culturally significant artifacts were deposited near the stelae, including unusual natural stones, fossils, pottery, arrowheads, and scatters of fire-altered human remains (Fedele 2004, 2008). Like Fosso Conicchio, the site was seemingly devoted to the processing of human remains during the liminal stage of the burial process, when the bones were removed from the grave and circulated among the living. This practice would have reinforced the cultural bonds tying together the living and the newly dead and secured their transformation into ancestors.

Insights into the cultural logic underpinning Copper Age bodies, both real and imagined, are provided by the diacritic signs defining personal identity on stelae and in articulated burials. The first is gender, which was expressed in a dichotomized form that differs from the more fluid representations of gender typical of Neolithic Italy (Robb 1994a, 2007; Whitehouse 1992b, 2001). In both stelae and burials, maleness is denoted through weapons, while femaleness is expressed through ornaments, especially necklaces. The second is age. As well as being gender-specific, 
the grave goods placed with articulated burials are also age-specific, as weapons and other markers of adulthood never accompany individuals under 11-12 years of age (Dolfini 2006a, b). Small stelae lacking breasts or weapons, often taken to indicate children, may mirror this funerary behavior (De Marinis 1995, p. 199; Robb 2009, p. 175). The third is the substances of the body. It is no coincidence that stelae where engraved in stone, as this material has distinctive physical and temporal properties such as endurance and immutability (Robb 2009). Stone was likely used in this context to emphasize a culturally constructed opposition between the living and the dead. Once again, this is something we encounter in burials, where ancestral bodies are defined by the hard, dry bones resulting from the decay of living (or transitioning) fleshed bodies. Stone may have stood for what the ancestors were made of (Bradley 1991, 2012; Parker Pearson and Ramilisonina 1998). Building on these considerations, I argue that the stone people should be interpreted as "special" ancestors, singled out by the living for distinct acts of remembrance. A similar practice was carried out at burial places by preserving the bodily integrity and furnishings of select deceased.

It appears that, in Copper Age central Italy, the dead could be channeled into two alternative pathways based on their personal identity, the circumstances of their death, and other factors that may no longer be discernible to us. The more common of the two-disarticulation-would have secured their integration into the undifferentiated realm of the collective ancestors; articulation, on the other hand, was reserved for select deceased whose life, death, or identity dictated singular, and perhaps individualized, commemoration.

\section{Understanding Late Neolithic and Copper Age Society in Central Italy}

Prevailing scholarly narratives maintain that three intertwined changes in central Italian settlement and subsistence strategies occurred during 4500-2200 BC: the breakup of the long-lived nucleated village, the colonization of marginal landscapes, and the onset of more diversified economic practices grounded in mobile herding. Since the fall of early migrationist theories, these changes have alternatively been explained as an unintended "snowball" effect caused by population growth (Barker 1981 , p. 158) or a response to drier and more unpredictable climatic regimes (Broodbank 2013, pp. 264-265). Social explanations have also been proposed that focus on the ethics of reciprocity engendered by meat consumption. This is conceptualized as a potent expression of intergroup relatedness, which would have intensified at a critical juncture marked by the stretching of social networks over a wider, less permanently settled landscape (Robb 2007, pp. 311-313).

In this review, I have nuanced this picture by showing that the change was less abrupt than previously surmised and that significant elements of continuity existed with earlier settlement patterns and economic regimes. I also have highlighted a plethora of regional differences that were likely motivated by distinctive social choices as well as environmental constraints. Within a broader trajectory toward more fragmented village communities, presumably breaking up along descent lines, one can discern a minority countertrend, which is especially visible in the fertile 
lowlands and alluvial plains. There, new productivity-boosting farming technologies allowed communities to stave off the growing risks of crop failure. It was, therefore, possible for them to dwell in large permanent settlements, which-and this is hardly a coincidence-reappeared in prehistoric Italy in the third millennium BC, following the widespread adoption of the plow and cart. Animal husbandry data display similar countertrends. For any community that intensified mobile herding, and set the mountains ablaze in the process, there were many others that took advantage of the naturally available meadows and deciduous woodlands surrounding their abode to sustain the year-round keeping of pig, sheep/goat, and cattle. For most of them, and perhaps all, mixed farming continued to be a pillar of the productive economy.

Such diverging approaches to subsistence, however, might have responded to an overarching principle that tied them all together. This is a new, more flexible concept of the residential group, which grew progressively disengaged from Neolithic ideas of the village as the place where the community would have dwelled together "since the beginning of time" (Dolfini 2015; Robb 2007). In the palimpsest of impermanent villages, dispersed farmsteads, and seasonally inhabited caves emerging from the late fifth millennium BC, one senses the ghost of large social units splintering along gender, age, and kin lines for subsistence tasks that took them away from the village and into the broader landscape. Tending to gardens, foraging in the woods, and moving the herds from pasture to pasture were now activities that might have characterized subsections of the social group more markedly than in the full Neolithic. Some of these tasks, such as hunting red deer during youth initiation rites and sharing the meat of a slaughtered cow to seal a marriage, would have served the purpose of reinforcing corporate identity as much as of supplementing a largely vegetarian diet.

As the tie between co-residence and the common history of the group stretched to a breaking point, burial was gradually reshaped as the medium around which social relations could newly coalesce (Dolfini 2015; Robb 1994b). This is perhaps unsurprising considering that, since the sixth millennium $\mathrm{BC}$, burial had been a prime means for ascribing group identity and structuring social interaction. Yet, as it changed in nature and grew in importance, burial underwent three profound alterations in its form and meaning. The first was a new social desire to create a special locus for the dead, separate from the living; the extramural cemetery was thus born. As I have argued, its waxing was concomitant to the slow waning of the nucleated village as a cultural resource. It could perhaps be said that the demise of the village, social if not always physical, necessitated the cemetery to be invented, insofar as smaller and more dispersed communities did require meaningful places to bury their dead, commemorate their ancestors, and ultimately reinforce the common genealogic ties that the new lifestyle had loosened.

The second alteration concerns the very nature of burial. Mortuary practices grew increasingly complex (but also normative and formulaic) in the Copper Age, to a degree unparalleled in the Neolithic world. This change may be explained with the growing importance of genealogy. Since kin group ancestors had become the core medium of social reproduction, a straightforward funerary rite no longer responded to the novel need to commune with them. Genealogy had to be played up to tie together the threads of a common history that the diminished role of the village had 
thrown into jeopardy. The ancestors, either real or conveniently "rediscovered," were the obvious means for doing so (Robb 1994b). In the fourth and third millennia BC, people increasingly defined themselves by handling, circulating, breaking, mixing, and reburying the physical bodies of their forebears in a bewildering array of ritual practices. Formally, such practices would have been justified by a richer and more subtle categorization of the deceased in terms of gender, age, and perhaps status (Fowler 2018). At a deeper level, however, they were motivated by a fresh desire to stress group identity and lineage ties across generations. Importantly, these practices required a grave structure that could be shared by the living, the newly dead, and the ancestors on equal footing; hence the chamber tomb and burial cave.

The third and perhaps deepest change lay in the social understanding of the human body. It appears that in central Italy, as elsewhere, the body was reconceptualized as a more partible and transgressible entity than it had been previously (Chapman 2000; Fowler 2008, 2015; Jones 2005). Body parts and substances endowed with symbolic qualities could now be extracted from the dead and employed in a wide range of ritual interactions and exchanges. Though hardly new, the practice grew in frequency, complexity, and social significance during the fourth and third millennia BC. Material culture played a major role in the process. As the bodies of the dead were broken up to secure their transformation into ancestors, their grave goods, presumably matched with specific body parts (e.g., head/battle-axe and limbs/arrows; Fig. 8), were recirculated among the living in mutually reinforcing signification processes. Comparatively rare articulated burials offer insights into the cultural logic underpinning this behavior. By using recurrent, stereotyped sets of goods, individual burials presented the identity of the dead as normative, institutionalized, and immutable (Dolfini 2006a, b). Such a significant countertrend to prevalent disarticulation practices has long attracted researchers' attention.

It is frequently suggested that the rich panoplies of stone and metal weapons accompanying articulated male bodies indicate that the deceased was invested in life with political leadership. Some see these individuals as the forerunners of a social archetype of the European Bronze Age: the "warrior-hero" (Hansen 2013; Jeunesse 2014). Following a well-rehearsed ethnographic analogy, others interpret them as

Fig. 8 Reconstructed layout of furnished male burial from Rinaldone, tomb 8. Note the stone battle-axe placed above the head, the metal dagger at the back of the head, and the two sets of flint arrowheads lying next to the limbs. The chamber grave had a south-facing entrance corridor; dimensions are unknown (Dolfini 2004)

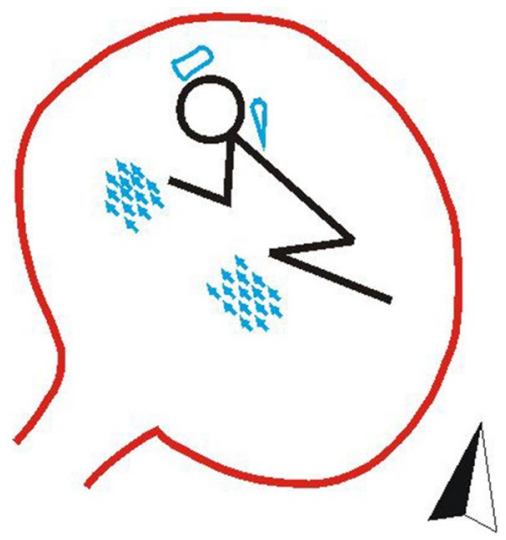


"Big Men" who would have grounded their power in the procurement and display of prestige-giving exotica (Cazzella 1998, 2003; Dolfini 2004). Both groups of scholars see in occasionally well-furnished child burials instances of ascribed status (Cazzella and Guidi 2011; Guidi 2000, pp. 58-59). This is taken as further proof that structured inequalities emerged at this time out of largely egalitarian Neolithic society. Robb (1999) has put forward a thought-provoking explanation for the emergence of social ranking in Late Neolithic and Copper Age Italy. He maintained that, in the Early and Middle Neolithic, the disparate forms of prestige created through various activities were not organized around unitary kinds of value associated with social eminence. One could be a religious leader, a master potter, or a fearsome warrior, but not all of them at once, for these domains of action were not commensurable. This changed from the late fifth millennium BC, and increasingly so in the fourth and third millennia, as personal prestige could first be accumulated by a person through manifold fields of action. Grounding their deeds in the new gender ideology gaining momentum at the time-Robb posited-successful political leaders could now rise to prominence and naturalize their claim to power through the display of iconic goods, first and foremost metal weapons. This would be a "great simplification" in sociopolitical structures akin to the shift from "Great Man" to "Big Man" societies in the ethnographic landscape of highland Papua New Guinea (see also Robb 2007).

While all these readings retain elements of value, I caution interpreting the social changes in overtly political terms. First, both Big Man and warrior-hero explanations focus on relatively infrequent articulated burials (especially if male and weaponrich) at the expense of widespread disarticulated, female, and poorly furnished inhumations. As we have seen, however, both articulation and disarticulation were employed in Copper Age Italy as meaningful funerary practices. They were ostensibly used for different categories of people based on aspects of their personal identity, the circumstances of their death, and other context-specific factors that may be difficult for us to map out. At several chamber grave cemeteries, moreover, and at all burial caves, no well-furnished articulated burials survive. Does it mean that these communities lacked political leaders worth remembering? Or did they dispense with structured leadership altogether? While these are, of course, possibilities worth considering, one could propose alternative explanations. These should focus on the broader cosmological meanings embodied by burial, including the desire to preserve the bodily integrity of select individuals in death and to reconfigure aspects of their personal identity in a highly stylized manner (Dolfini 2006a). In Copper Age Italy, not all routes to ancestorhood followed the same path. While most of the dead had their individual identities erased during the burial process, others had theirs refashioned following strict cultural norms and conventions. These were men, women, and children alike. Some were given identity-enhancing objects, others were not. Current political interpretations create an artificial separation between a few male, wellfurnished, articulated burials and "the rest." This invites caution in receiving them.

Second, current readings tend to overlook the complex taphonomy of Copper Age funerary sites. Most chamber graves, and virtually all burial caves, were venues for multiple interactions between the living and the dead; on occasion, these lasted for hundreds of years (Conti et al. 1997). At these sites, what we see as archaeologists 
is the final stage of the burial process, but we do not know (except for the articulated burials) how the process started, or, for that matter, how it unfolded. Political readings of Rinaldone-style and coeval burials are grounded in the unspoken assumption that lavish assemblages of goods were solely placed with the articulated dead. However, several clues suggest that this practice was far more prevalent than we can now appreciate, for objects were frequently moved out of the grave following the body parts to which they were symbolically tied. For example, funerary vessels and necklaces, which are invariably found broken and incomplete in reorganized burials, were laid whole at the time of the funeral (as seen in articulated burials). These objects were ostensibly fragmented and scattered during the burial process to create enchained relations (sensu Chapman 2000) linking the living, the newly dead, and the ancestors. This also may be true of the weapons occasionally found with disarticulated and commingled burials. Once again, readings focusing on the social need to express different kinds of identity in death and to erase or maintain it during the burial process might better account for the evidence than overtly political interpretations.

Third, sociopolitical explanations invariably assume that metals were intrinsically valuable and rare commodities in the Copper Age world. As the archetype of all prehistoric prestige goods, it is frequently presumed that metal was appropriated by self-aggrandizing individuals to naturalize their claims to power. However, largescale phenomena of metal accumulation, hoarding, and display are conspicuously absent in Copper Age central Italy; the richest individual burial known to date features six metal objects, while other alleged elite burials have merely one to four (Dolfini 2004, p. 227). In nearly all cases, metals are part of wider grave assemblages comprising flint, hardstone, and bone objects; there is nothing there, but our intrinsic bias, to underpin the belief that metalwork was more important or valuable because of the material of which it was made. Furthermore, it is not clear how rare a commodity copper was in early Italy. Though far from exhaustive, the latest research shows that much more ore was extracted and smelted, and much more copper was cast and used, than the archaeological record would have us believe (Lemorini 2012; Pearce 2009). As we have seen above, people routinely crafted and used metal tools at settlement sites, but these have become invisible due to widespread recycling. If metal was not a scarce commodity in early Italy, what was the source of its value? This might have resided in its striking visual and technological properties, or its novel funerary uses. Metal may have been valued for its unparalleled luminosity, its color palette, and its ability to be refashioned into new objects (and thus be inscribed with new meanings). Of course, it also was valued as a powerful diacritic for new gendered and aged personae (Dolfini 2008; Keates 2002; Robb and Harris 2013).

The notion that metal was the ultimate trigger of social inequality is usually compounded by the claim that it was exchanged over long distances as a prized, prestigegiving material. In this respect, too, established interpretations need nuancing, as the data do not point to a steady intensification of social interaction from late fifth to late third millennia $\mathrm{BC}$; they signal instead two separate trajectories: the peaking of long-distance communication and exchange in the late fifth millennium BC, and its sudden reversal to more self-contained circulation spheres in the early fourth millennium BC. Multiple, overlapping markers such as the exchange of Lipari obsidian 
and Alpine greenstone, as well as the spread of superregional pottery styles, hint at heightened connectivity in the Late Neolithic. However, these trade networks broke down abruptly, and all at the same time, in the Final Neolithic. In a time span of no more than two centuries, the reach of obsidian and greenstone receded from more than $1000 \mathrm{~km}$ to less than $200 \mathrm{~km}$, while once-pervasive pottery styles splintered into myriad craft traditions. New materials such as red jasper and steatite, and of course copper, came to the fore instead; long known to people, they had never elicited so much attention, by so many, prior to this time. Silver and antimony were perhaps the only materials to be genuinely new to Copper Age society. They might have been discovered by adapting copper reduction sequences to noncopper ores. Certainly, they were locally invested with social meanings stemming, it is presumed, from their unique white-silvery color, superb shine, and unparalleled reflectivity. All these materials, with the partial exception of metal, traveled no farther than $200 \mathrm{~km}$ from their sources, and often much less.

These considerations cast further doubts on the ability of power-hungry individuals to leverage the exchange of desirable artifacts for political purposes. Jasper, steatite, and most metal would have traveled through the network in a few days or weeks. Could control over them really attain political power? Even if they were displaced by longer lasting down-the-line or other indirect procurement mechanisms, it is unclear what special status could ever arise from objects that may have been within the reach of most adults in most communities (Robb and Harris 2013, p. 71). Compared with the sprawling web of Late Neolithic obsidian exchange, the Copper Age prestige goods economy, if it ever existed, must have had a decidedly local flavor. This is counterintuitive: if the power of distance bestowed tribal leaders with political authority, why did it wane when emerging Big Men would have needed it the most to consolidate their grip on increasingly scattered communities? Once again, we are left to wonder whether current political interpretations of Copper Age society are overstated. Rather than being the cradle of social inequality, I maintain, this period might be better understood as a turning point in the development of new cosmological beliefs and ideas of the person, laying the foundation for the Bronze Age world.

\section{Conclusion}

In providing a critical synthesis of the archaeology of Late Neolithic and Copper Age central Italy, 4500-2200 BC, and placing it in its wider peninsular context, I have discussed the latest research advances in the fields of relative and absolute chronology; settlement strategies and the productive economy; the circulation and exchange of socially significant materials; the rise of copper, silver, and antimony technology; and changes in funerary practices and ideas of the body. Specialists have frequently interpreted the new data in light of well-trodden narratives that stress the inevitable rise of social inequality, focusing on the appropriation of metals and other prestige goods to naturalize chiefs' claims to power and, for some authors, the right to transmit it to their offspring. 
I argue that the evidence should be interpreted differently. First, the idea that the long-distance trade of valuable substances would legitimize political power is problematic in the context of prehistoric Italy. Sought-after stone materials were widely exchanged in purportedly egalitarian Neolithic society, but their sprawling network came crashing down at the onset of the Copper Age. This is precisely the time when elites are alleged to rise. It is hard to imagine a worst time to rid society of a readily available source of prestige: the power of distance (Helms 1983). Proponents of these readings suggest that a shiny new valuable, metal, replaced early stone materials as the prestige good par excellence. Yet this is grounded more in an act of faith than in a dispassionate examination of the evidence.

Metals were doubtless important to Copper Age people; just consider the way they were used in carefully choreographed funerals. Yet they were too abundant and widespread to be sources of economic value, and they were used too often as mundane cutting tools (e.g., to work animal bone and steatite) to become the blanket prestige material that they are alleged to be. As for being exchanged over long distances, the jury is still out pending further provenance analyses. Based on the limited data presently available, however, it appears that most metals were procured locally, although some did come from faraway lands. Even those objects, however, were refashioned into familiar-looking axe heads and daggers by central Italian smiths; most likely, any memory of their being rare and prestigious exotica was lost on remelting (Dolfini et al., in press). Things undoubtedly changed in the Bronze Age, when tin trade once again connected distant regions of prehistoric Europe with one another. Prior to this time, however, the social value of metals was principally phenomenological, situational, and performative. Metals would have been appreciated for their unparalleled shine and luminosity, their ability to be inscribed with new meanings through recasting and refashioning, and their power to mark out increasingly salient gendered and aged identities in burial.

Furthermore, the pulverized settlement patterns that characterized central Italy from late fifth to late third millennia $\mathrm{BC}$ do not show power and resources being concentrated in emerging central places. Quite the opposite, as people lived more scattered and dispersed lives at this time than ever before. This began to change in the third millennium BC, when substantial villages were again established in fertile plains and river valleys due to improved farming technology. Even these settlements, however, lack the telltale markers of inequality seen, for example, at fortified Chalcolithic settlements in Iberia. Barring sensational new discoveries and revelations, Copper Age Italian settlements are best conceptualized as medium-to-large agrarian villages made possible by transformations in the productive economy. Their ditches and palisades were not constructed do defend the metal wealth of tribal chieftains but, more prosaically, the crops and animals of farming and herding communities.

Finally, I have argued that well-furnished individual burials should not be taken as proof of emerging political leadership — a reading that I, too, espoused earlier in my career (Dolfini 2004, 2006a). These interpretations stand on a selective reading of the burial record, focusing on a handful of articulated male inhumations at the expense of many hundreds of disarticulated, female, and poorly equipped burials; on a misinterpretation of the Copper Age funerary process, which possibly entailed a much higher number of organized and furnished interments than we see 
archaeologically; and on an overestimation of the importance of metals, which were invariably part of broader assemblages comprising stone and bone objects, too. Following Robb (2007) and Robb and Harris (2013), I have suggested that individual burials signal the rise of new forms of personal identity stressing gender, age, and other aspects of the deceased's personhood that may be harder for us to discern. Unlike them, however, I maintain that these burials can be understood only as part of a broader spectrum of funerary practices used by society to turn the newly dead into ancestral beings. This is especially the case in central Italy, where both articulation and disarticulation were meaningfully employed as legitimate pathways to ancestorhood. The former would have integrated the newly dead into the undifferentiated realm of the community's forebears, while the latter would have secured singular, and perhaps individualized, remembrance.

This does not mean that structured forms of leadership did not exist in early Italy, or that self-aggrandizers lacked opportunities to elevate their standing by manipulating multiple domains of action. What I have questioned instead is the idea that political power was single-mindedly expressed in the grave through supposedly rare and prestigious metal objects. Indeed, funerals and metalwork may have played a role in prehistoric power struggles, and they probably did. However, aspiring leaders would have maneuvered these media in more subtle, varying, and context-specific ways than current readings have us believe. Their strategies did not necessarily leave any discernible imprints in the burial record.

In this review, I have highlighted several problems deserving further research. First, the atomization of domestic pottery styles in the fourth and third millennia $\mathrm{BC}$, and the parallel growth of normative funerary ceramics over wide areas, invite social explanations away from worn-out and poorly theorized notions of the "archaeological culture." Second, the reappearance of substantial village communities in the third millennium $\mathrm{BC}$ requires dedicated research focused on the role of the plow and cart in their rise, and on the relationship between settled and mobile communities. Third, the imbalance between hyper-studied Neolithic obsidian and greenstone exchange and understudied Copper Age stone and metal trade must be addressed urgently. New research will clarify if the realignment in trade networks discussed above is as all-encompassing as it now appears; if metal became the new material affording wide-ranging exchange, and when it did so; and what social mechanisms and agents underpinned the new networks. Fourth, the evolution of copper smelting and working sorely needs reappraisal. Questions regarding the transformation of copper reduction technology from the Late Neolithic to the Late Copper Age bear important consequences for our understanding of technological change and knowledge transfer in early Italy. The same is true of metal casting, smithing, and working.

Perhaps the biggest challenge of all, however, lies in aligning Italian prehistoric studies with the growing amount of research into mobility and migration in Neolithic and Bronze Age Europe. Cutting-edge scientific methods including stable isotope analysis and ancient DNA sequencing are now being used to rewrite the early history of Europe (e.g., Kristiansen et al. 2017; Parker Pearson et al. 2016). Yet they have seldom been deployed to prehistoric Italy, with no studies yet available for the central peninsula, 4500-2200 BC. Out of many hundreds of Late Neolithic to Early Bronze Age Europeans whose ancient DNA has now been sequenced, only eight are 
from south of the Alps (at the time of writing); of these, seven are from northern Italy (including the famous Iceman mummy) and the eighth is from Sicily (Allentoft et al. 2015; Keller et al. 2012; Olalde et al. 2018; Sikora et al. 2014). As for stable isotope analysis highlighting residential mobility, the few studies published to date overlook the central peninsula, as well as much of the period in question (Cavazzuti et al. 2019; Tafuri et al. 2016).

Significantly, I have provided a critical context for evaluating mobility and migration in central Italy (as and when isotopic and genomic data will become available), preempting some of the more controversial interpretations proposed for the continental evidence. For example, the earliest instances of individual inhumation and warrior burial seem to predate the spread of steppe ancestry and related cultural phenomena across western Europe. It appears that, in Italy, the new burial customs arose out of internal dynamics rooted in Neolithic social practices. Moreover, I have raised fresh questions that could profitably be addressed through archaeological science. How was kinship expressed in burial? To what extent did the communities of the dead laid out in chamber tombs and burial caves reflect communities of the living? What social mechanisms underpinned the trade of valuable materials, and how did they change from the Neolithic to the Copper Age? Who was in charge of moving greenstone and obsidian over long distances, and who took care of the copper, jasper, and steatite? Did individuals move across vast geographical and social landscapes, or did they pass materials and objects down the line? Finally, did Italian society contribute to the spread of new ideas concerning burial and the body across prehistoric Europe? To what extent was Italy on the receiving end of the momentous social changes that affected the continent in the Late Neolithic and Chalcolithic, and to what extent did it contribute to them? The revised chronology discussed in these pages, assigning the birth of the Italian Copper Age to the mid-fourth millennium BC (a time predating the inception of Late Neolithic/Chalcolithic practices in most of western Europe), suggests that not all light may come from the Orient, after all. It is perhaps time that we started looking south.

Acknowledgments The ideas discussed in this article developed during 15 years of research into prehistoric central Italy. Many colleagues have contributed to their shaping, but I wish to acknowledge here those who have exerted the greatest influence, namely my BA dissertation supervisor and long-term mentor, Dr. Nuccia Negroni Catacchio; my MA thesis supervisor, Professor R. C. De Marinis; and my Ph.D., supervisors, Professors G. Barker and J. E. Robb. I thank Gilberto Artioli, Ivana Angelini, and Cristiano Iaia for enhancing my studies of early Italian metallurgy. I am grateful to Francesco Carrer, Vanessa Forte, Chris Fowler, Cristiano Iaia, Mark Pearce, Robin Skeates, and the anonymous JARE reviewers for commenting on earlier versions of this work; to Giovanni Carboni for custom-assembling Fig. 2; and to Eleonora Montanari for helping with the bibliography and images. All opinions and errors are mine.

Open Access This article is licensed under a Creative Commons Attribution 4.0 International License, which permits use, sharing, adaptation, distribution and reproduction in any medium or format, as long as you give appropriate credit to the original author(s) and the source, provide a link to the Creative Commons licence, and indicate if changes were made. The images or other third party material in this article are included in the article's Creative Commons licence, unless indicated otherwise in a credit line to the material. If material is not included in the article's Creative Commons licence and your intended use is not permitted by statutory regulation or exceeds the permitted use, you will need to obtain permission directly from the copyright holder. To view a copy of this licence, visit https://creativecommons.org/licen ses/by/4.0/. 


\section{References Cited}

Allen, H. D. (2003). Response of past and present Mediterranean ecosystems to environmental change. Progress in Physical Geography 27: 359-377.

Allentoft, M. E., Sikora, M., Sjögren, K. G., Rasmussen, S., Rasmussen, M., Stenderup, J., et al. (2015). Population genomics of Bronze Age Eurasia. Nature 522: 167-172.

Ambert, P., Bouquet, L., Guendon, J. L., and Mischka, D. (2005). La Capitelle du Broum (district minier de Cabrières-Péret, Hérault): Établissement industriel de l'aurore de la métallurgie française (3100-2400 BC). In Ambert, P., and Vaquer, J. (eds.), La première métallurgie en France et dans les pays limitrophes, Société Préhistorique Française, Paris, pp. 83-96.

Ambert, P., Balestro, F., Laroche, M., Figueroa, V., and Rovira, S. (2013). Technological aspects of the earliest metallurgy in France: 'Furnaces' and slags from La Capitelle du Broum (Péret, France). Historical Metallurgy 47: 60-74.

Ambrosi, A. C., and Mannoni, T. (1972). Il primo scavo di una statua-stele scoperta in situ (Minucciano III). Rivista di Studi Liguri 38: 244-255.

Ammerman, A. J. (1985). The Acconia Survey: Neolithic Settlement and Obsidian Trade, Institute of Archaeology, London.

Ammerman, A. J. (2003). The circulation of obsidian in Italy during the Neolithic period. In Atti della XXXV Riunione Scientifica dell'Istituto Italiano di Preistoria e Protostoria, Istituto Italiano di Preistoria e Protostoria, Florence, pp. 547-557.

Ammerman, A. J., and Polglase, C. (1993). The exchange of obsidian at Neolithic sites in Italy. In Healy, F., and Scarre, C. (eds.), Trade and Exchange in European Prehistory, Oxbow, Oxford, pp. 101-107.

Anthony, D. W. (2007). The Horse, the Wheel, and Language: How Bronze-Age Riders from the Eurasian Steppes Shaped the Modern World, Princeton University Press, Princeton.

Anzidei, A. P., and Carboni, G. (1995). L'insediamento preistorico di Quadrato di Torre Spaccata (Roma) e osservazioni su alcuni aspetti tardo-neolitici ed eneolitici nell'Italia centrale. Origini 19: 55-255.

Anzidei, A. P., and Carboni, G. (2007). Il villaggio neo-eneolitico di Quadrato di Torre Spaccata (Roma): Nuovi dati dagli scavi del Giubileo 2000. In Atti della XL Riunione Scientifica dell'Istituto Italiano di Preistoria e Protostoria, vol. II, Istituto Italiano di Preistoria e Protostoria, Florence, pp. 421-435.

Anzidei, A. P., and Zarattini, A. (2007). Il Neolitico e l'Eneolitico nel Lazio centro-meridionale: Aspetti culturali e scelte insediamentali. In Atti della XL Riunione Scientifica dell'Istituto Italiano di Preistoria e Protostoria, Istituto Italiano di Preistoria e Protostoria, Florence, pp. 79-100.

Anzidei, A. P., Carboni, G., and Celant, A. (2002). Il popolamento del territorio di Roma nel Neolitico recente/finale: Aspetti culturali ed ambientali. In Ferrari, A., and Visentini, P. (eds.), Il declino del mondo neolitico, Museo Archeologico del Friuli Occidentale, Pordenone, pp. 473-482.

Anzidei, A. P., Carboni, G., Carboni, L., Catalano, P., Celant, A, Cereghino, R., et al. (2011a). Il Gaudo a sud del Tevere: Abitati e necropoli dell'area romana. In Atti della XLIII Riunione Scientifica dell'Istituto Italiano di Preistoria e Protostoria, Istituto Italiano di Preistoria e Protostoria, Florence, pp. 309-321.

Anzidei, A. P., Carboni, G., Carboni, L., Castagna, M. A., Catalano, P., Egidi, R., Malvone, R., and Spadoni, D. (2011b). Il gruppo Roma-Colli Albani della facies di Rinaldone: organizzazione spaziale, rituali e cultura materiale nelle necropoli di Lucrezia Romana e Romanina (Roma). In Atti della XLIII Riunione Scientifica dell'Istituto Italiano di Preistoria e Protostoria, Istituto Italiano di Preistoria e Protostoria, Florence, pp. 297-307.

Anzidei, A. P., Carboni, G., and Mieli, G. (2012). Il gruppo Roma-Colli Albani: Un decennio di ricerche e studi sulla facies di Rinaldone nel territorio di Roma. In Negroni Catacchio, N. (ed.), Preistoria e protostoria in Etruria: Atti del X Incontro di Studi, Centro Studi di Preistoria e Archeologia, Milan, pp. 197-214.

Anzidei, A. P., Aurisicchio, C., Carboni, G., Catalano, P., De Angelis, F., Di Giannantonio, S., et al. (2018). La necropoli eneolitica di Casetta Mistici (Roma): Corredi personali con armi metalliche, in pietra e dati antropologici come indicatori di status sociale e di circolazione di uomini e di oggetti nell'ambito della cultura di Rinaldone. In Negroni Catacchio, N. (ed.), Preistoria e protostoria in Etruria: Atti del XIII Incontro di Studi, Centro Studi di Preistoria e Archeologia, Milan, pp. 117-130. 
Aranguren, B., and Sozzi, M. (2006). Nuovi dati sulle attività estrattive e fusorie nell'età del Bronzo a Massa Marittima (Grosseto). In Atti della XXXIX Riunione Scientifica dell'Istituto Italiano di Preistoria e Protostoria, vol. III, Istituto Italiano di Preistoria e Protostoria, Florence, pp. 1422-1425.

Artioli, G. (2007). Crystallographic texture analysis of archaeological metals: Interpretation of manufacturing techniques. Applied Physics A 89: 899-908.

Artioli, G., Angelini, I., Burger, D., Bougarit, E., and Colpani, F. (2007). Petrographic and chemical investigations of the earliest copper smelting slags in Italy: Towards a reconstruction of the beginning of copper metallurgy. In Archaeometallurgy in Europe, Papers of the 2nd International Conference (CD issue, slag session), Associazione Italiana di Metallurgia, Milan, pp. 1-9.

Artioli, G., Angelini, I., Addis, A., Canovaro, C., Chiarantini, L., and Benvenuti, M. (2016). Ceramiche tecniche, scorie, minerali e metalli: Interpretazione del processo metallurgico. In Fedeli, F., and Galiberti, A. (eds.), Metalli e metallurghi della preistoria: L'insediamento eneolitico di San CarloCava Solvay, Tagete, Pontedera, pp. 69-81.

Artioli, G., Angelini, I., Kaufmann, G., Canovaro, C., Dal Sasso, G., and Villa, I. M. (2017). Long-distance connections in the Copper Age: New evidence from the Alpine Iceman's copper axe. PLOS ONE 12(7): e0179263.

Barfield, L. H. (1966). Excavations on the Rocca di Rivoli (Verona) 1963 and the prehistoric sequence in the Rivoli basin. Memorie del Museo Civico di Storia Naturale di Verona 14: 1-100.

Barfield, L. H. (1996). The Chalcolithic in Italy: Considerations of metal typology and cultural interactions. In Bagolini, B., and Lo Schiavo, F. (eds.), The Copper Age in the Near East and Europe, XIX Colloquium of the XIII UISPP Congress, Abaco, Forlì, pp. 65-74.

Barfield, L. H. (1999). Neolithic and Copper Age flint exploitation in northern Italy. In Della Casa, Ph. (ed.), Prehistoric Alpine Environment, Society and Economy, Habelt, Bonn, pp. 245-252.

Barker, G. (1971). The first metallurgy in Italy in the light of the metal analyses from the Pigorini Museum. Bullettino di Paletnologia Italiana 80: 183-212.

Barker, G. (1981). Landscape and Society: Prehistoric Central Italy, Academic Press, London.

Barker, G. (2005). Agriculture, pastoralism, and Mediterranean landscapes in prehistory. In Blake, E., and Knapp, A. B. (eds.), The Archaeology of Mediterranean Prehistory, Blackwell, Oxford, pp. 46-76.

Barker, G., and Grant, A. (1991). Ancient and modern pastoralism in central Italy: An interdisciplinary study in the Cicolano Mountains. Papers of the British School at Rome 59: 15-88.

Barker, G., Biagi, P., Clark, G., Maggi, R., and Nisbet, R. (1990). From hunting to herding in the Val Pennavaira (Liguria - northern Italy). In Biagi, P. (ed.), The Neolithisation of the Alpine Region, Museo Civico di Scienze Naturali, Brescia, pp. 99-121.

Barrett, J. C. (1994). Fragments from Antiquity: An Archaeology of Social Life in Britain, 2900-1200 BC, Blackwell, Oxford.

Bellotti, P. (2017). La laguna e i suoi tomboli: Meccanismi di formazione e caratteri sedimentologici. In Negroni Catacchio, N., Cardosa, M., and Dolfini, A. (eds.), Paesaggi d'Acque: La laguna di Orbetello e il Monte Argentario tra preistoria ed età romana, Centro Studi di Preistoria e Archeologia, Milan, pp. 296-301.

Bernabò Brea, M., Bianchi, P., Bronzoni, L., and Mazzieri, P. (2011). Abitati dell'età del Rame nel Parmense. In Atti della XLIII Riunione Scientifica dell'Istituto Italiano di Preistoria e Protostoria, Istituto Italiano di Preistoria e Protostoria, Florence, pp. 233-247.

Bernabò Brea, M., Bertolotti, P., Bronzoni, L., and Miari, M. (2013). Gli insediamenti di pianura a sud del Po. In De Marinis, R. C. (ed.), L'età del Rame: La Pianura Padana e le Alpi al tempo di Ötzi, Massetti Rodella, Brescia, pp. 251-266.

Bianco Peroni, V. (1994). I Pugnali nell'Italia Continentale, Prähistorische Bronzefunde, VI.10, Franz Steiner, Stuttgart.

Bietti Sestieri, A. M., and Gianni, A. (1984). L'insediamento eneolitico di Piscina di Torre Spaccata. In Bietti Sestieri, A. M. (ed.), Preistoria e protostoria nel territorio di Roma, De Luca, Rome, pp. 142-159.

Bistolfi, F., and Muntoni, I. (2000). L'Eneolitico nella media valle del Sacco: Aspetti funerari e insediativi. In Silvestrini, M. (ed.), Recenti acquisizioni, problemi e prospettive della ricerca sull'Eneolitico dell'Italia centrale, Regione Marche, Ancona, pp. 265-291.

Blondel, J., Aronson, J., Bodiou, J. Y., and Boeuf, G. (2010). The Mediterranean Region: Biological Diversity in Space and Time, Oxford University Press, Oxford.

Boccuccia, P., Carboni, G., Gioia, P., and Remotti, E. (2000). Il sito di Casale del Cavaliere (Roma) e l'Eneolitico dell'Italia centrale: Problemi di inquadramento cronologico e culturale alla luce della 
recente datazione radiometrica. In Silvestrini, M. (ed.), Recenti acquisizioni, problemi e prospettive della ricerca sull'Eneolitico dell'Italia centrale, Regione Marche, Ancona, pp. 231-247.

Bourdieu, P. (1977). Outline of a Theory of Practice, Cambridge University Press, Cambridge.

Bourgarit, D. (2007). Chalcolithic copper smelting. In La Niece, S., Hook, D., and Craddock, P. (eds.), Metals and Mines: Studies in Archaeometallurgy, British Museum, London, pp. 3-14.

Bradley, R. (1991). Ritual, time and history. World Archaeology 23: 209-219.

Bradley, R. (2012). The Significance of Monuments: On the Shaping of Human Experience in Neolithic and Bronze Age Europe, Routledge, London.

Braithwaite, M. (1984). Ritual and prestige in the prehistory of Wessex c. 2,200-1,400 BC: A new dimension to the archaeological evidence. In Miller, D., and Tilley, C. (eds.), Ideology, Power and Prehistory, Cambridge University Press, Cambridge, pp. 93-110.

Branch, N. P., and Marini, N. A. (2014). Mid-Late Holocene environmental change and human activities in the northern Apennines, Italy. Quaternary International 353: 34-51.

Broodbank, C. (2013). The Making of the Middle Sea, Thames and Hudson, London.

Bulgarelli, M. G., and Giumlia-Mair, A. (2008). Un anellino metallico dal sito Neo-Eneolitico di Poggio Olivastro (Canino,Viterbo). In Petitti, P., and Rossi, F. (eds.), Aes: Metalli preistorici dalla Tuscia, Museo della Preistoria della Tuscia, Valentano, pp. 12-13.

Bulgarelli, G. M., D’Erme, L., Pellegrini, E., and Petitti, P. (1993). L'insediamento preistorico di Poggio Olivastro (Canino, Viterbo): Considerazioni e prospettive. Bullettino di Paletnologia Italiana 84: 435-480.

Bulgarelli, G. M., D’Erme, L., and Pellegrini, E. (2000). Le evidenze eneolitiche dal sito di Poggio Olivastro (Canino, Viterbo). In Silvestrini, M. (ed.), Recenti acquisizioni, problemi e prospettive della ricerca sull'Eneolitico dell'Italia centrale, Regione Marche, Ancona, pp. 191-201.

Campana, N., and Maggi, R. (eds.) (2002). Archeologia in Valle Lagorara: Diecimila anni di storia intorno a una cava di diaspro, Istituto Italiano di Preistoria e Protostoria, Florence.

Campana, N., Franceschi, E., Maggi, R., and Stos-Gale, Z. A. (1996). Grotticella sepolcrale di Val Frascarese (Genova): Nuove analisi dei reperti metallici. In Cocchi Genick, D. (ed.), L'antica età del Bronzo in Italia, Octavo, Florence, pp. 556-557.

Campana, N., Maggi, R., and Negrino, F. (1998). Le cave di diaspro di Valle Lagorara e Boschi di Liciorno (Maissana - SP). In Del Lucchese, A., and Maggi, R. (eds.), Dal diaspro al bronzo: L'età del Rame e del Bronzo in Liguria: 26 secoli di storia fra 3600 e 1000 anni avanti Cristo, Luna Editore, La Spezia, pp. 145-147.

Carancini, G. L. (1993). Primi sviluppi della metallurgia nell'area medio-tirrenica nel quadro della protostoria peninsulare. In Petitti, P. (ed.), Vulcano a Mezzano: Insediamento e produzioni artigianali nella Media Valle del Fiora Durante l'età del Bronzo, Comune di Valentano, Valentano, pp. 125-150.

Carancini, G. L. (2001). Origini e sviluppi della metallurgia in Toscana nell'ambito delle fasi più antiche della protostoria. In Atti della XXXIV Riunione Scientifica dell'Istituto Italiano di Preistoria e Protostoria, Istituto Italiano di Preistoria e Protostoria, Florence, pp. 235-249.

Carboni, G., Celant, A., Forte, V., Magri, D., Nunziante Cesaro, S., and Anzidei, A.P. (2015). Inebriarsi per l'aldilà: Bevande alcoliche nelle necropoli di facies Rinaldone e Gaudo dell'area romana. In Atti della L Riunione Scientifica dell'Istituto Italiano di Preistoria e Protostoria, Online Conference Papers, http://www.preistoriadelcibo.it/sessione4-download.html

Carobbi, G., and Rodolico, F. (1976). I minerali della Toscana: Saggio di mineralogia regionale, Olschki, Florence.

Casini, S. (ed.) (1994). Le pietre degli dei: Menhir e stele dell'età del Rame in Valcamonica e Valtellina, Comune di Bergamo, Bergamo.

Casini, S., and Fossati, A. E. (2013). Immagini di dei, guerrieri e donne: Stele, massi incisi e arte rupestre dell'età del Rame in Valcamonica e Valtellina. In De Marinis, R. C. (ed.), L'età del Rame. La Pianura Padana e le Alpi al tempo di Ötzi, Massetti Rodella, Brescia, pp. 161-196.

Cavanna, C., and Pellegrini, E. (2007). La Buca di Spaccasasso: Ricerche 2000-2004. In Cavanna, C. (ed.), La preistoria nelle grotte del parco naturale della Maremma, Museo di Storia Naturale della Maremma, Grosseto, pp. 117-136.

Cavazzuti, C., Skeates, R., Millard, A. R., Nowell, G., Peterkin, J., Bernabò Brea, M., Cardarelli, A., and Salzani, L. (2019). Flows of people in villages and large centres in Bronze Age Italy through strontium and oxygen isotopes. PLOS ONE 14(1): e0209693.

Cavinato, A. (1964). Giacimenti minerari, Utet, Torino. 
Cazzella, A. (1994). Dating the Copper Age in the Italian Peninsula and adjacent islands. Journal of European Archaeology 2(1): 1-19.

Cazzella, A. (1998). Modelli e variabilità negli usi funerari di alcuni contesti eneolitici italiani. Rivista di Scienze Preistoriche 49: 431-445.

Cazzella, A. (1999). Il fossato di Conelle di Arcevia. In Cazzella, A., and Moscoloni, M. (eds.), Conelle di Arcevia: Un insediamento eneolitico nelle Marche, Gangemi, Rome, pp. 1-12.

Cazzella, A. (2003). Rituali funerari eneolitici nell'Italia peninsulare: L'Italia centrale. In Atti della XXXV Riunione Scientifica dell'Istituto Italiano di Preistoria e Protostoria, vol. I, Istituto Italiano di Preistoria e Protostoria, Florence, pp. 275-282.

Cazzella, A., and Guidi, A. (2011). Il concetto di Eneolitico in Italia. In Atti della XLIII Riunione Scientifica dell'Istituto Italiano di Preistoria e Protostoria, Istituto Italiano di Preistoria e Protostoria, Florence, pp. 25-32.

Cazzella, A., and Moscoloni, M. (eds.) (1999). Conelle di Arcevia: Un insediamento eneolitico nelle Marche, Gangemi, Rome.

Cerqua, M. (2011). Selva dei Muli (Frosinone): Un insediamento eneolitico della facies del Gaudo. Origini 33: 157-248.

Chapman, J. (2000). Fragmentation in Archaeology: People, Places and Broken Objects in the Prehistory of the South-Eastern Europe, Routledge, London.

Chapman, R. (2003). Archaeologies of Complexity, Routledge, London.

Childe, V. G. (1929). The Danube in Prehistory, Oxford University Press, Oxford.

Childe, V. G. (1957). The Dawn of European Civilization, 6th ed., Routledge and Kegan Paul, London.

Cocchi Genick, D. (1994). Manuale di Preistoria, II: Il Neolitico, Octavo, Florence.

Cocchi Genick, D. (1996). Manuale di Preistoria, III.: L'età del Rame, Octavo, Florence.

Cocchi Genick, D. (2004). Considerazioni sull'ideologia religiosa nell'Eneolitico italiano. Bullettino di Paletnologia Italiana 95: 83-126.

Cocchi Genick, D. (2008). La tipologia in funzione della ricostruzione storica: Le forme vascolari dell'età del Rame dell'Italia centrale, Istituto Italiano di Preistoria e Protostoria, Florence.

Cocchi Genick, D. (2009). Preistoria, QuiEdit, Verona.

Cocchi Genick, D. (2013a). I nuovi dati nell'ambito del quadro generale e delle problematiche dell'Eneolitico italiano. In Cocchi Genick, D. (ed.), Cronologia assoluta e relativa dell'età del Rame in Italia, QuiEdit, Verona, pp. 233-261.

Cocchi Genick, D. (ed.) (2013b). Cronologia assoluta e relativa dell'età del Rame in Italia, QuiEdit, Verona.

Cocchi Genick, D., and Grifoni Cremonesi, R. (1989). L'età del Rame in Toscana, Comune di Viareggio, Viareggio.

Colombaroli, D., Marchetto, A., and Tinner, W. (2007). Long-term interactions between Mediterranean climate, vegetation and fire regime at Lago di Massaciuccoli (Tuscany, Italy). Journal of Ecology 95: 755-770.

Coltorti, M. (1997). Human impact in the Holocene fluvial and coastal evolution of the Marche region, central Italy. Catena 30: 311-335.

Conati Barbaro, C. (2007-2008). Custodire la memoria: Le sepolture in abitato nel Neolitico italiano. Scienze dell'Antichità 14: 49-70.

Conti, A. M., Persiani, C., and Petitti, P. (1997). I riti della morte nella necropoli eneolitica della Selvicciola (Ischia di Castro, Viterbo). Origini 21: 169-185.

Craddock, P. (1995). Early Metal Mining and Production, Edinburgh University Press, Edinburgh.

Crellin, R. J. (2018). Examining the British and Irish Early Bronze Age flat axes of the Greenwell Collection at the British Museum. Journal of Archaeological Science: Reports 18: 858-888.

Cremaschi, M., Nicosia, C., and Salvioni, M. (2011). L'uso del suolo nell'Eneolitico e nel Bronzo antico: Nuovi dati dalla pianura padana centrale, in Atti della XLIII Riunione Scientifica dell'Istituto Italiano di Preistoria e Protostoria, Istituto Italiano di Preistoria e Protostoria, Florence, pp. 225-231.

Cremonesi, G. (1965). Il villaggio di Ripoli alla luce dei recenti scavi. Rivista di Scienze Preistoriche 20: $85-155$.

Cremonesi, G. (1976). La Grotta dei Piccioni di Bolognano nel quadro delle culture dal Neolitico all'età del Bronzo in Abruzzo, Giardini, Pisa.

Cremonesi, G. (2001). La grotta sepolcrale eneolitica di San Giuseppe all'Isola d'Elba, Istituto Italiano di Preistoria e Protostoria, Florence. 
Cristiani, E., and Alhaique, F. (2005). Selce o metallo? Approccio sperimentale all'analisi delle modalità di manifattura degli strumenti in materia dura animale presso Conelle di Arcevia (Ancona). In Atti della XXXVIII Riunione Scientifica dell'Istituto Italiano di Preistoria e Protostoria, vol. II, Istituto Italiano di Preistoria e Protostoria, Florence, pp. 939-943.

Curci, A., and Tagliacozzo, A. (1994). Il pozzetto rituale con scheletro di cavallo dall'abitato eneolitico di Maccarese. Origini 18: 297-350.

Curci, A., and Tagliacozzo, A. (2002). Il pozzetto rituale con scheletro di cavallo dall'abitato eneolitico di Le Cerquete-Fianello (Maccarese, Fiumicino). In Manfredini, A. (ed.), Le dune, il lago, il mare: Una comunità di villaggio dell'età del Rame a Maccarese, Istituto Italiano di Preistoria e Protostoria, Florence, pp. 238-245.

Davis, B. A. S., Brewer, S., Stevenson, A. C., and Guiot, J. (2003). The temperature of Europe during the Holocene reconstructed from pollen data. Quaternary Science Reviews 22: 1701-1716.

De Marinis, R. C. (1995). Le statue-stele della Lunigiana. Notizie Archeologiche Bergomensi 3: 195-212.

De Marinis, R. C. (2000). Il Museo Civico Archeologico Giovanni Rambotti: Una introduzione alla preistoria del lago di Garda, Comune di Desenzano del Garda, Desenzano.

De Marinis, R. C. (2006). Aspetti della metallurgia dell'età del Rame e dell'antica età del Bronzo in Toscana. Rivista di Scienze Preistoriche 56: 211-272.

Dolfini, A. (2004). La necropoli di Rinaldone (Montefiascone, Viterbo): Rituale funerario e dinamiche sociali di una comunità eneolitica in Italia centrale. Bullettino di Paletnologia Italiana 95 : $127-278$.

Dolfini, A. (2006a). Embodied inequalities: Burial and social differentiation in Copper Age central Italy. Archaeological Review from Cambridge 21(2): 58-77.

Dolfini, A. (2006b). L'inumazione primaria come sistema simbolico e pratica sociale. In Negroni Catacchio, N. (ed.), Preistoria e protostoria in Etruria: Atti del VII Incontro di Studi, vol. II, Centro Studi di Preistoria e Archeologia, Milan, pp. 461-472.

Dolfini, A. (2008). Making Sense of Technological Innovation: The Adoption of Metallurgy in Prehistoric Central Italy, Ph.D. dissertation, Department of Archaeology, University of Cambridge, Cambridge.

Dolfini, A. (2010). The origins of metallurgy in central Italy: New radiometric evidence. Antiquity 84: $707-723$.

Dolfini, A. (2011). The function of Chalcolithic metalwork in Italy: An assessment based on use-wear analysis. Journal of Archaeological Science 38: 1037-1049.

Dolfini, A. (2013a). Early metallurgy in the central Mediterranean: Goals for the next decade. Historical Metallurgy 47: 33-50.

Dolfini, A. (2013b). The emergence of metallurgy in the central Mediterranean region: A new model. European Journal of Archaeology 16: 21-62.

Dolfini, A. (2013c). The Neolithic beginnings of metallurgy in the central Mediterranean region. Accordia Research Papers 13: 131-151

Dolfini, A. (2014). Early metallurgy in the central Mediterranean. In Roberts, B. W., and Thornton, C. P. (eds.), Archaeometallurgy in Global Perspective, Springer, New York, pp. 473-506.

Dolfini, A. (2015). Neolithic and Copper Age mortuary practices in the Italian peninsula: Change of meaning or change of medium? In Brandt, J. R., Ingvaldsen, H., and Prusac, M. (eds.), Death and Changing Rituals: Function and Meaning in Ancient Funerary Practices, Oxbow, Oxford, pp. $17-44$.

Dolfini, A. (2017). Neolitico, Eneolitico ed età del Bronzo. In Negroni Catacchio, N., Cardosa, M., and Dolfini, A. (eds.), Paesaggi d'Acque: La laguna di Orbetello e il Monte Argentario tra preistoria ed età Romana, Centro Studi di Preistoria e Archeologia, Milan, pp. 310-327.

Dolfini, A., Angelini, I., and Artioli, G. (in press). Copper to Tuscany - Coals to Newcastle? The dynamics of metalwork exchange in early Italy. PLOS ONE.

Fedele, F. (2004). Monoliths and human skeletal remains: Ritual manipulation at the Anvòia ceremonial site, Ossimo (Val Camonica, Italy). Notizie Archeologiche Bergomensi 12: 49-66.

Fedele, F. (2008). Statue-menhirs, human remains and Mana at the Ossimo 'Anvòia' ceremonial site, Val Camonica. Journal of Mediterranean Archaeology 21: 57-79.

Fedeli, F., and Galiberti, A. (eds.) (2016). Metalli e metallurghi della preistoria: L'insediamento eneolitico di San Carlo-Cava Solvay, Tagete, Pontedera.

Follieri, M., Magri, D., and Sadori, L. (1989). Pollen stratigraphical synthesis from Valle di Castiglione (Roma). Quaternary International 3-4: 81-84. 
Forte, V., and Medeghini, L. (2017). A preliminary study of ceramic pastes in the Copper Age pottery production of the Rome area. Archaeological and Anthropological Sciences 9: 209-222.

Fowler, C. (2008). Fractal bodies in the past and present. In Borić, D., and Robb, J. E. (eds.), Past bodies: Body-centred research in Archaeology, Oxbow, Oxford, pp. 47-58.

Fowler, C. (2015). Change and continuity in Early Bronze Age mortuary rites: A case study from Northumberland. In Brandt, J. R., Ingvaldsen, H., and Prusac, M. (eds.), Death and Changing Rituals: Function and Meaning in Ancient Funerary Practices, Oxbow, Oxford, pp. 45-91.

Fowler, C. (2018). Personhood, the life course and mortuary practices in Mesolithic, Neolithic and Chalcolithic Europe. In Nizzo, V. (ed.), Archeologia e antropologia della morte, 2: Corpi, relazioni e azioni: Il paesaggio del rito, École Française, Rome, pp. 83-118.

Fugazzola Delpino, M. A., and Pellegrini, E. (1999). Il complesso cultuale 'campaniforme' di Fosso Conicchio (Viterbo). Bullettino di Paletnologia Italiana 90: 61-159.

Fugazzola Delpino, M. A., Manfredini, A., Martini, F., Radi, G., Sarti, L., and Silvestrini, M. (2003). Insediamenti e strutture neolitiche ed eneolitiche dell'Italia centrale. In Atti della XXXV Riunione Scientifica dell'Istituto Italiano di Preistoria e Protostoria, vol. I, Istituto Italiano di Preistoria e Protostoria, Florence, pp. 93-112.

Fugazzola Delpino, M. A., Salerno, A., and Tinè, V. (2007). Villaggi e necropoli dell'area 'Centro Commerciale' di Gricignano d'Aversa - US Navy (Caserta). In Atti della XL Riunione Scientifica dell'Istituto Italiano di Preistoria e Protostoria, vol. II, Istituto Italiano di Preistoria e Protostoria, Florence, pp. 521-537.

Furholt, M. (2018). Massive migrations? The impact of recent aDNA studies on our view of third millennium Europe. European Journal of Archaeology 21: 159-191.

Garcia, S. L., and Murillo-Barroso, M. (2013). Social complexity in Copper Age southern Iberia (ca. 3200-2200 cal. BC): Reviewing the 'state' hypothesis at Valencina de la Conception (Seville, Spain). In Cruz, M., Garcia, L., and Gilman, A. (eds), The Prehistory of Iberia: Debating Early Social Stratification and the State, Routledge, London, pp. 119-140.

Gernone, P. (1998). Pianaccia di Suvero: Atelier per la lavorazione della steatite. In Del Lucchese, A., and Maggi, R. (eds.), Dal diaspro al bronzo: L'età del Rame e del Bronzo in Liguria: 26 secoli di storia fra 3600 e 1000 anni avanti Cristo, Luna Editore, La Spezia, pp. 161-163

Gianni, A. (1991). Il farro, il cervo ed il villaggio mobile. Scienze dell'Antichità 5: 99-161.

Giardino, C. (1998). I metalli nel mondo antico: Introduzione all'archeometallurgia, Laterza, Rome.

Giardino, C. (2009-12). From natural resources to cultural commodities: Metal technology in the central and south Italian Copper Age. Accordia Research Papers 12: 15-40.

Giardino, C., and Steiniger, D. (2011). Evidenze di miniere preistoriche nell'Etruria meridionale. In Giardino, C. (ed.), Archeometallurgia: Dalla conoscenza alla fruizione, Edipuglia, Bari, pp. 289-292.

Gilman, A. (1991). Trajectories towards social complexity in the later prehistory of the Mediterranean. In Earle, T. (ed.), Chiefdoms: Power, Economy, and Ideology, Cambridge University Press, Cambridge, pp. 146-168.

Gimbutas, M. (1977). The first wave of Eurasian pastoralists into Copper Age Europe. Journal of IndoEuropean Studies 5: 277-338.

Giraudi, C., Magny, M., Zanchetta, G., and Drysdale, R. N. (2011). The Holocene climatic evolution of Mediterranean Italy: A review of the continental geological data. The Holocene 21: 105-115.

Graziosi, P. (1996). The Prehistoric Paintings of the Porto Badisco Cave, Istituto Italiano di Preistoria e Protostoria, Florence.

Greenfield, H. J. (2010). The secondary products revolution: The past, the present and the future. World Archaeology 42: 29-54.

Grifoni Cremonesi, R. (2003a). Sepolture neolitiche dell'Italia centro-meridionale e loro relazione con gli abitati. In Atti della XXXV Riunione Scientifica dell'Istituto Italiano di Preistoria e Protostoria, vol. I., Istituto Italiano di Preistoria e Protostoria, Florence, pp. 259-274.

Grifoni Cremonesi, R. (2003b). Il Neolitico dell'Abruzzo. In Atti della XXXVI Riunione Scientifica dell'Istituto Italiano di Preistoria e Protostoria, Istituto Italiano di Preistoria e Protostoria, Florence, pp. 127-143.

Grifoni Cremonesi, R., Radi, G., and Sarti, L. (2001). Il Neolitico della Toscana. In Atti della XXXIV Riunione Scientifica dell'Istituto Italiano di Preistoria e Protostoria, Istituto Italiano di Preistoria e Protostoria, Florence, pp. 57-70. 
Gross, E., Schaeren, G., and Villa, I. M. (2017). The copper axe blade of Zug-Riedmatt, Canton of Zug, Switzerland: A key to chronology and metallurgy in the second half of the fourth millennium BC. Archäologische Informationen 40: 213-227.

Grunewald, K., and Scheithauer, J. (2010). Europe's southernmost glaciers: Response and adaptation to climate change. Journal of Glaciology 56: 129-142.

Guidi, A. (2000). Preistoria della complessità sociale, Laterza, Rome.

Guidi, A., and Piperno, M. (ed.) (1992). Italia preistorica, Laterza, Rome.

Guilaine, J. (2018). Siret's smile. Antiquity 92: 1247-1259.

Gutherz, X., and Jallot, L. (1995). Le Néolithique final du Languedoc méditerranéen. In Voruz, J.-L. (ed.), Chronologies néolithiques: De 6000 à 2000 avant notre ère dans le bassin rhodanien, Société Préhistorique Rhodanienne, Ambérieu-en-Bugey, pp. 231-263.

Haak, W., Lazaridis, I., Patterson, N., Rohland, N., Mallick, S., Llamas, B., et al. (2015). Massive migration from the steppe was a source for Indo-European languages in Europe. Nature 522: 207-211.

Hansen, S. (2013). The birth of the hero: The emergence of a social type in the 4th millenium BC. In Starnini, E. (ed.), Unconformist Archaeology: Papers in Honour of Paolo Biagi, Archaeopress, Oxford, pp. 101-112.

Harrison, R., and Heyd, V. (2007). The transformation of Europe in the third millennium BC: The example of 'Le Petit-Chasseur I+III (Sion, Valais, Switzerland). Praehistorische Zeitschrift 82: $129-214$.

Helms, M. W. (1983). Ulysses' Sail: An Ethnographic Odyssey of Power, Knowledge, and Geographical Distance, Princeton University Press, Princeton.

Heyd, V. (2007). Families, prestige goods, warriors and complex societies: Beaker groups and the 3rd millennium cal BC. Proceedings of the Prehistoric Society 73: 327-381.

Heyd, V. (2013). L'europa nell'età del Rame: La 'calcolitizzazione' di un continente. In De Marinis, R.C. (ed.), L'età del Rame: La pianura padana e le Alpi al tempo di Ötzi, Massetti Rodella, Brescia, pp. 23-38.

Heyd, V. (2017). Kossinna's smile. Antiquity 91: 348-359.

Hofmann, D. (2015). What have genetics ever done for us? The implications of aDNA data for interpreting identity in Early Neolithic central Europe. European Journal of Archaeology 18: 454-476.

Horden, P., and Purcell, N. (2000). The Corrupting Sea: A Study of Mediterranean History, Blackwell, Oxford.

Iaia, C., and Dolfini, A. (in press). Manufatti eneolitici in lega di rame dall'area di Roma: Un'indagine su tracce di processi tecnologici e di usura. In Anzidei, A. P., and Carboni G. (eds.), Roma prima del mito: Abitati e necropoli dal neolitico alla prima eta' dei metalli nel territorio di Roma (VI-III millennio a.C.), Istituto Italiano di Preistoria e Protostoria, Florence.

Jeunesse, C. (2014). Emergence of the warrior in the western Mediterranean during the second half of the fourth millennium BC. Eurasia Antiqua 14: 171-184.

Jones, A. M. (2005). Lives in fragments? Personhood and the European Neolithic. Journal of Social Archaeology 5: 193-224.

Keates, S. (2002). The flashing blade: Copper, colour and luminosity in North Italian Copper Age society. In Jones, A., and MacGregor, G. (eds.), Colouring the Past: The Significance of Colour in Archaeological Research, Berg, Oxford, pp. 109-125.

Keller, A., Graefen, A., Ball, M., Matzas, M., Boisguerin, V., Maixner, F., et al. (2012). New insights into the Tyrolean Iceman's origin and phenotype as inferred by whole-genome sequencing. Nature communications 3: 698-707.

Kienlin, T. L. (2008). Tradition and innovation in Copper Age metallurgy: Results of a metallographic examination of flat axes from eastern central Europe and the Carpathian Basin. Proceedings of the Prehistoric Society 74: 79-107.

Kienlin, T. L. (2010). Traditions and Transformations: Approaches to Eneolithic (Copper Age) and Bronze Age Metalworking and Society in Eastern Central Europe and the Carpathian Basin, Archaeopress, Oxford.

Killick, D. (2014). From ores to metals. In Roberts, B. W., and Thornton, C. P. (eds.), Archaeometallurgy in Global Perspective, Springer, New York, pp. 11-45.

Kristiansen, K. (2015). The decline of the Neolithic and the rise of Bronze Age society. In Fowler, C., Harding, J., and Hofmann, D. (eds.), The Oxford Handbook of Neolithic Europe, Oxford University Press, Oxford, pp. 1093-1117. 
Kristiansen, K., Allentoft, M. E., Frei, K. M., Iversen, R., Johannsen, N. N., Kroonen, G., et al. (2017). Re-theorising mobility and the formation of culture and language among the Corded Ware Culture in Europe. Antiquity 91: 334-347.

Kuijpers, M. H. (2018). An Archaeology of Skill: Metalworking Skill and Material Specialization in Early Bronze Age Central Europe, Routledge, London.

Laforgia, E., and Boenzi, G. (2011). Nuovi dati sull'Eneolitico della piana campana dagli scavi A.V. in provincia di Napoli. In Atti della XLIII Riunione Scientifica dell'Istituto Italiano di Preistoria e Protostoria, Istituto Italiano di Preistoria e Protostoria, Florence, pp. 249-255.

Laviosa Zambotti, P. (1943). Le più antiche culture agricole europee, Principato, Milan.

Leighton, R., and Dixon, J. (1992). Jade and greenstone in the prehistory of Sicily and southern Italy. Oxford Journal of Archaeology 11: 179-200.

Lemorini, C. (2012). Buried without metal: The role of the lithic kit in Chalcolithic funerary contexts of the Marche region (central Italy). In Conati Barbaro, C., and Lemorini, C. (eds.), Social, Economic and Symbolic Perspectives at the Dawn of Metal Production, Archaeopress, Oxford, pp. 33-40.

Leonini, V., Sarti, L., and Volante, N. (2013). La cronologia dell'età del Rame in area fiorentina nel quadro dell'Italia centrale tirrenica: Stato dell'arte e nuove datazioni. In Cocchi Genick, D. (ed.), Cronologia assoluta e relativa dell'età del Rame in Italia, QuiEdit, Verona, pp. 67-80.

Lotti, B. (1910). Memorie descrittive della Carta Geologica d'Italia, volume XIII: Geologia della Toscana, Regio Ufficio Geologico, Rome.

Maggi, R. (ed.) (1997). Arene Candide: A Functional and Environmental Assessment of the Holocene Sequence (Excavations Bernabò Brea and Cardini 1940-50), Istituto Italiano di Paleontologia Umana, Rome.

Maggi, R. (2001). Pietre della memoria. In Martinelli, M. C., and Spigo, U. (eds.), Studi di Preistoria e Protostoria in onore di Luigi Bernabò Brea, Regione Sicilia, Palermo, pp. 175-86.

Maggi, R. (2002). Pastori, miniere, metallurgia nella transizione fra Neolitico ed età del Rame: Nuovi dati dalla Liguria. In Ferrari, A., and Visentini, P. (eds.), Il declino del mondo neolitico, Museo Archeologico del Friuli Occidentale, Pordenone, pp. 437-440.

Maggi, R., and De Pascale, A. (2011). Fire making water on the Ligurian Apennines. In van Leusen, M., Pizziolo, G., and Sarti, L. (eds.), Hidden Landscapes of Mediterranean Europe, Archaeopress, Oxford, pp. 105-112.

Maggi, R., and Formicola, V. (1978). Una grotticella sepolcrale dell'inizio dell'età del Bronzo in Val Frascarese (Genova). Preistoria Alpina 14: 87-113.

Maggi, R., and Pearce, M. (2005). Mid fourth-millennium copper mining in Liguria, north-west Italy: The earliest known copper mines in western Europe. Antiquity 79: 66-77.

Maggi, R., and Pearce, M. (2013). Cronologia mineraria in Liguria. In Cocchi Genick, D. (ed.), Cronologia assoluta e relativa dell'età del Rame in Italia, QuiEdit, Verona, pp. 5-15.

Magny, M., De Beaulieu, J. L., Drescher-Schneider, R., Vannière, B., Walter-Simonnet, A. V., Miras, Y., et al. (2007). Holocene climate changes in the central Mediterranean as recorded by lake-level fluctuations at Lake Accesa (Tuscany, Italy). Quaternary Science Reviews 26: 1736-1758.

Magri, D., and Sadori, L. (1999). Late Pleistocene and Holocene pollen stratigraphy at Lago di Vico, central Italy. Vegetation History and Archaeobotany 8: 247-260.

Mallory, J. P. (1989). In Search of the Indo-Europeans, Thames and Hudson, London.

Malone, C. (1986). Exchange systems and Styles in the Central Mediterranean, 4500-1700 BC, Ph.D. dissertation, Department of Archaeology, University of Cambridge, Cambridge.

Malone, C. (2003). The Italian Neolithic: A synthesis of research. Journal of World Prehistory 17: $235-312$.

Manfredini, A. (2001). Rituali funerari e organizzazione sociale: Una rilettura di alcuni dati della facies Diana in Italia meridionale. In Martinelli, M. C., and Spigo, U. (eds.), Studi di preistoria e protostoria in onore di Luigi Bernabò Brea, Museo Archeologico Regionale Eoliano, Lipari, pp. 71-87.

Manfredini, A. (ed.) (2002). Le dune, il lago, il mare: Una comunità di villaggio dell'età del Rame a Maccarese, Istituto Italiano di Preistoria e Protostoria, Florence.

Manfredini, A., Sarti, L., and Silvestrini, M. (2005a). Il Neolitico delle Marche. In Atti della XXXVIII Riunione Scientifica dell'Istituto Italiano di Preistoria e Protostoria, vol. I, Istituto Italiano di Preistoria e Protostoria, Florence, pp. 197-208.

Manfredini, A., Carboni, G., Conati Barbaro, C., Silvestrini, M., Fiorentino, G., and Corridi, C. (2005b). La frequentazione eneolitica di Maddalena di Muccia (Macerata). In Atti della XXXVIII Riunione Scientifica dell'Istituto Italiano di Preistoria e Protostoria, vol. I, Istituto Italiano di Preistoria e Protostoria, Florence, pp. 433-444. 
Manfredini, A., Fugazzola Delpino, M. A., Sarti, L., Silvestrini, M., Martini, F., Conati Barbaro, C., et al. (2009). Adriatico e Tirreno a confronto. Rivista di Scienze Preistoriche 59: 115-180.

Mazzieri, P., and Dal Santo, N. (2007). Il sito del Neolitico recente di Botteghino (Parma). Rivista di Scienze Preistoriche 57: 113-138.

Mazzini, U. (1909). Statue-menhirs della Lunigiana. Bullettino di Paletnologia Italiana 35: 65-77.

Melis, M. G. (2009). L'Eneolitico antico, medio ed evoluto in Sardegna: Dalla fine dell'Ozieri all'Abealzu. In Atti della XLIV Riunione Scientifica dell'Istituto Italiano di Preistoria e Protostoria, vol. I, Istituto Italiano di Preistoria e Protostoria, Florence, pp. 81-109.

Mezzena, F. (1998). Le stele antropomorfe nell'area megalitica di Aosta. In Dei di Pietra: La grande statuaria antropomorfa nell'Europa del III millennio a.C., Skira, Milano, pp. 90-127.

Miari, M. (1995). Il rituale funerario della necropoli eneolitica di Ponte S. Pietro (Ischia di Castro, Viterbo). Origini 18: 351-390.

Mochi, A. (1915). Indizi di miniere preistoriche di cinabro nella regione dell'Amiata. Bullettino di Paletnologia Italiana 41: 5-12.

Moscoloni, M., and Silvestrini, M. (2005). Gli insediamenti eneolitici delle Marche. In Atti della XXXVIII Riunione Scientifica dell'Istituto Italiano di Preistoria e Protostoria, vol. I, Istituto Italiano di Preistoria e Protostoria, Florence, pp. 421-431.

Negroni Catacchio, N. (2006). La cultura di Rinaldone. In Negroni Catacchio, N. (ed.), Preistoria e protostoria in Etruria: Atti del VII Incontro di Studi, vol. I, Centro Studi di Preistoria e Archeologia, Milan, pp. 31-45.

Negroni Catacchio, N., and Miari, M. (1995). La necropoli rinaldoniana di Fontanile di Raim (Ischia di Castro, Viterbo). In Negroni Catacchio, N. (ed.), Preistoria e protostoria in Etruria: Atti del III Incontro di Studi, Octavo, Florence, pp. 391-400.

Negroni Catacchio, N., Pacciani, E., Albertini, E., Aspesi, M., and Moggi-Cecchi, J. (2014). Nuovi dati su alcune necropoli rinaldoniane: Revisioni di vecchi scavi, nuove datazioni e recenti analisi dei resti scheletrici. Rivista di Scienze Preistoriche 64: 83-113.

Olalde, I., Brace, S., Allentoft, M. E., Armit, I., Kristiansen, K., Booth, T., et al. (2018). The Beaker phenomenon and the genomic transformation of northwest Europe. Nature 555: 190-196.

Palma di Cesnola, A. (1967). Il neolitico medio e superiore di San Domino (Arcipelago delle Tremiti). Rivista di Scienze Preistoriche 22: 349-391.

Palmieri, A. M., and Cazzella, A. (1999). Manufatti metallici. In Cazzella, A., and Moscoloni, M. (eds.), Conelle di Arcevia: Un insediamento eneolitico nelle Marche, Gangemi, Rome, pp. 205-208.

Pare, C. (2000). Bronze and the Bronze Age. In Pare, C. (ed.), Metals Make the World Go Round, Oxbow, Oxford, pp. 1-38.

Parker Pearson, M., and Ramilisonina (1998). Stonehenge for the ancestors: The stones pass on the message. Antiquity 72: 308-326.

Pearson, M. P., Chamberlain, A., Jay, M., Richards, M., Sheridan, A., Curtis, N., et al. (2016). Beaker people in Britain: Migration, mobility and diet. Antiquity 90: 620-637.

Pearce, M. (2007). Bright Blades and Red Metal: Essays on North Italian Prehistoric Metalwork, Accordia Research Institute, London.

Pearce, M. (2009). How much metal was there in circulation in Copper Age Italy? In Kienlin, T. L., and Roberts, B. W. (eds.), Metals and Societies: Studies in Honour of Barbara S. Ottaway, Rudolf Habelt, Bonn, pp. 277-284.

Peet, T. E. (1909). The Stone and Bronze Ages in Italy, Oxford University Press, Oxford.

Perini, R. (1983). Der frühbronzezeitliche Pflug von Lavagnone. Archäologisches Korrespondenzblatt 13: $187-195$.

Perini, R. (1992). Evidence of metallurgical activity in Trentino from Chalcolithic times to the end of the Bronze Age. In Antonacci Sanpaolo, E. (ed.), Archeometallurgia: Ricerche e prospettive, Cooperativa Libraria Universitaria, Bologna, pp. 53-80.

Pernicka, E. (2014). Provenance determination of archaeological metal objects. In Roberts, B. W., and Thornton, C. P. (eds.), Archaeometallurgy in Global Perspective, Springer, New York, pp. 239-268.

Peroni, R. (1971). L'età del Bronzo nella penisola italiana I: L'antica età del Bronzo, Accademia Toscana di Scienze e Lettere 'La Colombaria,' Florence.

Peroni, R. (1989). Protostoria dell'Italia continentale: La penisola italiana nelle età del Bronzo e del Ferro, Biblioteca di storia patria, Rome.

Peroni, R. (1996). L'Italia alle Soglie della Storia, Laterza, Rome. 
Perucchetti, L., Bray, P., Dolfini, A., and Pollard, A. M. (2015). Physical barriers, cultural connections: Prehistoric metallurgy across the alpine region. European Journal of Archaeology 18: 599-632.

Pessina, A., and Radi, G. (2002). L'aspetto di Fossacesia e il Neolitico recente dell'Italia centroadriatica. In Ferrari, A., and Videntini, P. (eds.), Il declino del mondo neolitico, Museo Archeologico del Friuli Occidentale, Pordenone, pp. 139-156.

Pessina, A., and Radi, G. (2003). Il Neolitico recente e finale in Abruzzo. In Atti della XXXVI Riunione Scientifica dell'Istituto Italiano di Preistoria e Protostoria, Istituto Italiano di Preistoria e Protostoria, Florence, pp. 209-218.

Pessina, A., and Radi, G. (2005). La diffusione dell'ossidiana nell'Italia centro-settentrionale.In Atti della XXXIX Riunione Scientifica dell'Istituto Italiano di Preistoria e Protostoria, vol. I, Istituto Italiano di Preistoria e Protostoria, Florence, pp. 435-460.

Pessina, A., and Tiné, V. (2008). Archeologia del Neolitico: L'Italia tra VI e IV millennio a.C, Carocci, Rome.

Petitti, P., Negroni Catacchio, N., Conti, A. M., Lemorini, C., and Persiani, C. (2002). La necropoli eneolitica del Fontanile di Raim: Nuovi dati sulla campagna di scavo 1998. In Negroni Catacchio, N. (ed.), Preistoria e protostoria in Etruria: Atti del V Incontro di Studi, vol. II, Centro Studi di Preistoria e Archeologia, Milan, pp. 545-568.

Petitti, P., Persiani, C., and Pallecchi, P. (2011). Reperti metallici dalla necropoli della Selvicciola (Ischia di Castro - Viterbo). In Atti della XLIII Riunione Scientifica dell'Istituto Italiano di Preistoria e Protostoria, Istituto Italiano di Preistoria e Protostoria, Florence, pp. 187-194.

Pétrequin, P., Sheridan, A., Cassen, S., Errera, M., Gauthier, E., Klassen, L., Le Maux, N., and Y. Pailler, (2008). Neolithic Alpine axeheads, from the Continent to Great Britain, the Isle of Man and Ireland. Analecta Praehistorica Leidensia 40: 261-279.

Puglisi, S. M. (1959). La civiltà appenninica: Origine delle comunità pastorali in Italia, Sansoni, Florence.

Quagliati, Q. (1906). Tombe neolitiche in Taranto e nel suo territorio. Bullettino di Paletnologia Italiana 30: $17-49$.

Radivojević, M., Roberts, B. W., Pernicka, E., Stos-Gale, Z., Martinón-Torres, M., Rehren, T., et al. (2019). The provenance, use, and circulation of metals in the European Bronze Age: The state of debate. Journal of Archaeological Research 27: 131-185.

Radmilli, A. M. (1975). Guida della preistoria italiana, Sansoni, Florence.

Rellini, U. (1934). La più antica ceramica dipinta in Italia, Collezione Meridionale, Rome.

Renfrew, C., and Whitehouse, R. (1974). The Copper Age of peninsular Italy and the Aegean. The Annual of the British School at Athens 69: 343-390.

Robb, J. E. (1994a). Gender contradictions, moral coalitions, and inequality in prehistoric Italy. Journal of European Archaeology 2(1): 20-49.

Robb, J. E. (1994b). Burial and social reproduction in the peninsular Italian Neolithic. Journal of Mediterranean Archaeology 7: 27-71.

Robb, J. E. (1999). Great Persons and Big Men in the Italian Neolithic. In Tykot, R. H., Morter, J., and Robb, J. E. (eds.), Social Dynamics of the Prehistoric Central Mediterranean, Accordia Research Institute, London, pp. 111-121.

Robb, J. E. (2002). Time and biography: Osteobiography of the Italian Neolithic lifespan. In Hamilakis, Y., Pluciennik, M., and Tarlow, S. (eds.), Thinking through the Body: Archaeologies of Corporeality, Kluwer Academic/Plenum, London, pp. 153-171.

Robb, J. E. (2007). The Early Mediterranean Village: Agency, Material Culture, and Social Change in Neolithic Italy, Cambridge University Press, Cambridge.

Robb, J. E. (2008). Tradition and agency: Human body representations in later prehistoric Europe. World Archaeology 40: 332-353.

Robb, J. E. (2009). People of stone: Stelae, personhood, and society in prehistoric Europe. Journal of Archaeological Method and Theory 16: 162-183.

Robb, J. E., and Farr, H. (2005). Substances in motion: Neolithic Mediterranean 'trade.' In Blake, E., and Knapp, A. B. (eds.), The Archaeology of Mediterranean Prehistory, Blackwell, Oxford, pp. 24-45.

Robb, J. E., and Harris, O. J. (eds.) (2013). The Body in History: Europe from the Palaeolithic to the Future, Cambridge University Press, Cambridge.

Roberts, B. W., Thornton, C., and Pigott, V. C. (2009). Development of metallurgy in Eurasia. Antiquity 83: $1012-1022$.

Roberts, N., Brayshaw, D., Kuzucuoğlu, C., Perez, R., and Sadori, L. (2011). The mid-Holocene climatic transition in the Mediterranean: Causes and consequences. The Holocene 21: 3-13. 
Sadori L., Jahns, S., and Peyron, O. (2011). Mid-Holocene vegetation history of the central Mediterranean. The Holocene 21: 117-129.

Sarti, L. (1995-96). Cronostratigrafia del Campaniforme in area fiorentina: Dati preliminari dall'insediamento di Lastruccia. Rivista di Scienze Preistoriche 47: 239-260.

Sarti, L. (ed.) (1997). Querciola: Insediamento campaniforme a Sesto Fiorentino, Garlatti and Razzai, Florence.

Sarti, L. (1998). Aspetti insediativi del Campaniforme in Italia centrale. In Nicolis, F., and Mottes, E. (eds.), Simbolo ed enigma: Il Bicchiere Campaniforme e l'Italia nella preistoria del III millennio a.C, Provincia Autonoma di Trento, Trento, pp. 137-153.

Sarti, L., and Martini, F. (2001). Strategie insediative del Campaniforme nell'Italia centrale tirrenica. In Nicolis, F. (ed.), Bell Beakers Today: Pottery, People, Culture, Symbols in Prehistoric Europe, Vol. I, Provincia Autonoma di Trento, Trento, pp. 187-198.

Sarti, L., Silvestrini, M., and Volante, N. (2005). Il Neolitico recente-finale tra il medio versante adriatico e l'alto versante tirrenico. In Atti della XXXVIII Riunione Scientifica dell'Istituto Italiano di Preistoria e Protostoria, Istituto Italiano di Preistoria e Protostoria, Florence, pp. 259-278.

Shennan, S. (1982). Ideology, change and the European Early Bronze Age. In Hodder, I. (ed.), Symbolic and Structural Archaeology, Cambridge University Press, Cambridge, pp. 155-161.

Sherratt, A. G. (1981). Plough and pastoralism: Aspects of the secondary products revolution. In Hodder, I., Isaac, G., and Hammond, N. (eds.), Pattern of the Past: Studies in Honour of David Clarke, Cambridge University Press, Cambridge, pp. 261-305.

Sherratt, A. (1983). The secondary exploitation of animals in the Old World. World Archaeology 15: 90-104.

Sherratt, A. (1993). What would a Bronze-Age world system look like? Relations between temperate Europe and the Mediterranean in later prehistory. Journal of European Archaeology 1(2): 1-58.

Saccoccio, F., Marzocchella, A., and Vanzetti, A. (2013). The field system of Gricignano d'Aversa (Southern Italy) and the agrarian impact in the Piana Campana, ca. 3900 cal BP. Quaternary International 303: 82-92.

Sikora, M., Carpenter, M. L., Moreno-Estrada, A., Henn, B. M., Underhill, P. A., Sánchez-Quinto, F., et al. (2014). Population genomic analysis of ancient and modern genomes yields new insights into the genetic ancestry of the Tyrolean Iceman and the genetic structure of Europe. PLOS Genetics 10(5): e1004353.

Silvestrini, M., Baglioni, L., Carlini, C., Casciarri, S., Frediani, A., Freguglia, M., et al. (2002). Il Neolitico tardo-finale delle Marche: Primi dati da S. Maria in Selva (Treia, Macerata). In Ferrari, A., and Videntini, P. (eds.), Il declino del mondo neolitico, Museo Archeologico del Friuli Occidentale, Pordenone, pp. 453-459.

Skeates, R. (1993). Early metal-use in the central Mediterranean region. Accordia Research Papers 4: $5-48$

Skeates, R. (1996). Towards an absolute chronology for the Copper Age in central Italy: A note based on the Conelle site and culture. Papers of the British School at Rome 64: 273-282.

Skeates, R. (1995a). Transformations in mortuary practice and meaning in the Neolithic and Copper Age of lowland east-central Italy. In Waldren, W. H., Ensenyat, J. A., and Kennard, R. C. (eds.), Ritual, Rites and Religion in Prehistory, Archaeopress, Oxford, pp. 211-237.

Skeates, R. (1995b). Animate objects: A biography of prehistoric 'axe-amulets' in the central Mediterranean region. Proceedings of the Prehistoric Society 61: 279-301.

Skeates, R. (1997a). Copper Age settlement and economy in Marche, central Italy: A social perspective. Journal of Mediterranean Archaeology 10: 49-72.

Skeates, R. (1997b). The human use of caves in east-central Italy during the Mesolithic, Neolithic and Copper Age. In Bonsall, C., and Tolan-Smith, C. (eds.), The Human Use of Caves, Archaeopress, Oxford, pp. 79-86.

Skeates, R. (2003). Prehistoric chert exploitation in the Valle del Cesolone (Macerata): A preliminary project report. Papers of the British School at Rome 71: 1-15.

Skeates, R. (2013). Neolithic Italy at 4004 BC: People and places. Accordia Research Papers 13: $1-29$.

Spindler, K. (1971). Zur Herstellung der Zinnbronze in der frühen Metallurgie Europas. Acta Praehistorica et Archaeologica 2: 199-253.

Strahm, C. (2007). L'introduction de la métallurgie en Europe. In Guilaine, J. (ed.), Le Chalcolithique et la construction des inégalités, Errance, Paris, pp. 49-71. 
Strahm, C., and Hauptmann, A. (2009). The metallurgical developmental phases in the Old World. In Kienlin, T. L., and Roberts, B. W. (eds), Metals and Societies: Studies in Honour of Barbara $S$. Ottaway, Rudolf Habelt, Bonn, pp. 116-128.

Tafuri, M. A., Fullagar, P. D., O’Connell, T. C., Belcastro, M. G., Iacumin, P., Conati Barbaro, C., Sanseverino, R, and Robb, J. E. (2016). Life and death in Neolithic southeastern Italy: The strontium isotopic evidence. International Journal of Osteoarchaeology 26: 1045-1057.

Tarantini, M., and Galimberti, A. (eds.) (2011). Le miniere di selce del Gargano, VI-III millennio a.C. Alle origini della storia mineraria europea, All'Insegna del Giglio, Florence.

Thomas, J. (2002). Understanding the Neolithic, Routledge, London.

Thorpe, I. J., and Richards, C. (1984). The decline of ritual authority and the introduction of Beakers into Britain. In Bradley, R., and Gardiner, J. (eds.), Neolithic Studies: A Review of Some Current Research, British Archaeological Reports, Oxford, pp. 67-78.

Tozzi, C., and Zamagni, B. (2003). Gli scavi nel villaggio Neolitico di Catignano (1971-1980), Istituto Italiano di Preistoria e Protostoria, Florence.

Trump, D. H. (1966). Central and Southern Italy before Rome, Thames and Hudson, London.

Tykot, R. H. (1998). Mediterranean islands and multiple flows: The sources and exploitation of Sardinian obsidian. In Shackley, M. S. (ed.), Archaeological Obsidian Studies, Plenum, New York, pp. 67-82.

Tykot, R. H. (2017). Obsidian studies in the prehistoric central Mediterranean: After 50 years, what have we learned and what still needs to be done? Open Archaeology 3: 264-278.

Tykot, R. H., and Ammerman, A. J. (1997). New directions in central Mediterranean obsidian studies. Antiquity 71: 1000-1006.

Van Gennep, A. (1909). Les rites de passage, Nourry, Paris.

Vander Linden, M. (2006). For whom the bell tolls: Social hierarchy vs. social integration in the Bell Beaker culture of southern France (third millennium BC). Cambridge Archaeological Journal 16: 317-332.

Vander Linden, M. (2016). Population history in third millennium BC Europe: Assessing the contribution of genetics. World Archaeology 48: 714-728.

Vaquer, J. (1990). Le néolithique en Languedoc occidental, Centre National de la Recherche Scientifique, Paris.

Vaquer, J. (2006). La diffusion de l'obsidienne dans le Néolitique de Corse, du Midi de la France et de la Catalogne. In Atti della XXXIX Riunione Scientifica dell'Istituto Italiano di Preistoria e Protostoria, vol. I, Istituto Italiano di Preistoria e Protostoria, Florence, pp. 483-498.

Vigliardi, A. (ed.) (2002). La Grotta del Fontino: Una cavità funeraria eneolitica del Grossetano, Museo Fiorentino di Preistoria 'Paolo Graziosi,' Florence.

Volante, N. (2014). La collina di Spaccasasso: Evidenze funerarie e minerarie nel Parco regionale della Maremma: Nuovi dati. In Negroni Catacchio, N. (ed.), Preistoria e protostoria in Etruria: Atti dell'XI Incontro di Studi, vol. II, Centro Studi di Preistoria e Archeologia, Milan, pp. 625-636.

Walker, D. S. (1967). A Geography of Italy, 2nd ed., Methuen, London.

Walsh, K. (2014). The Archaeology of Mediterranean Landscapes: Human-Environment Interaction from the Neolithic to the Roman Period, Cambridge University Press, Cambridge.

Whitehouse, R. D. (1992a). Underground Religion: Cult and Culture in Prehistoric Italy, Accordia Research Institute, London.

Whitehouse, R. D. (1992b). Tools the manmaker: The cultural construction of gender in Italian prehistory. Accordia Research Papers 3: 41-53.

Whitehouse, R. D. (2001). Exploring gender in prehistoric Italy. Papers of the British School at Rome 68 : 49-96.

Whittle, A. (1996). Europe in the Neolithic: The Creation of New Worlds, Cambridge University Press, Cambridge.

Wilkens, B. (2000). Allevamento e caccia: Le tendenze economiche di alcuni siti durante l'Eneolitico. In Silvestrini, M. (ed.), Recenti acquisizioni, problemi e prospettive della ricerca sull'Eneolitico dell'Italia centrale, Regione Marche, Ancona, pp. 319-324.

\section{Bibliography of Recent Literature}

Atti della XXXIV Riunione Scientifica dell'Istituto Italiano di Preistoria e Protostoria. (2001). Preistoria e protostoria della Toscana, Istituto Italiano di Preistoria e Protostoria, Florence. 
Atti della XXXV Riunione Scientifica dell'Istituto Italiano di Preistoria e Protostoria. (2003). Le comunità della preistoria italiana, Istituto Italiano di Preistoria e Protostoria, Florence.

Atti della XXXVI Riunione Scientifica dell'Istituto Italiano di Preistoria e Protostoria. (2003). Preistoria e protostoria dell'Abruzzo, Istituto Italiano di Preistoria e Protostoria, Florence.

Atti della XXXVIII Riunione Scientifica dell'Istituto Italiano di Preistoria e Protostoria. (2005). Preistoria e protostoria delle Marche, Istituto Italiano di Preistoria e Protostoria, Florence.

Atti della XXXIX Riunione Scientifica dell'Istituto Italiano di Preistoria e Protostoria. (2006). Materie prime e scambi nella preistoria italiana, Istituto Italiano di Preistoria e Protostoria, Florence.

Atti della XL Riunione Scientifica dell'Istituto Italiano di Preistoria e Protostoria. (2007). Strategie di insediamento tra Lazio e Campania in età preistorica e protostorica, Istituto Italiano di Preistoria e Protostoria, Florence.

Atti della XLIII Riunione Scientifica dell'Istituto Italiano di Preistoria e Protostoria (2011). L'età del Rame in Italia, Istituto Italiano di Preistoria e Protostoria, Florence.

Barfield, L. H. (ed.) (2007). Excavations in the Riparo Valtenesi, Manerba 1976-1994, Istituto Italiano di Preistoria e Protostoria, Florence.

Bietti Sestieri, A. M., and Macnamara, E. (2007). Prehistoric Metal Artefacts from Italy (3500-720 BC) in the British Museum, British Museum, London.

Casini, S., and Fossati, A. (eds.) (2004). Le Pietre degli Dei: Statue-stele dell'età del Rame in Europa: Lo stato della ricerca, Special issue of Notizie Archeologiche Bergomensi 12.

Cazzella, A., Moscoloni, M., and Recchia, G. (eds.) (2003). Conelle di Arcevia: Tecnologia e contatti culturali nel Mediterraneo centrale fra IV e III millennio aC, Gangemi, Roma.

Conati Barbaro, C., Cristiani, E., and Lemorini, C. (2010). The lithic perspective: Reading Copper Age society by means of techno-functional approach. Human Evolution 25: 143-154.

De Marinis, R. C. (ed.) (2013). L'età del Rame: La pianura padana e le Alpi al tempo di Ötzi, Massetti Rodella, Brescia.

Fiori, O., Fornai, C., and Manzi, G. (2004). Ai confini del Gaudo: Una riconsiderazione dei resti scheletrici umani provenienti dai siti eneolitici di Canatalupo Mandela e Valvisciolo (Lazio meridionale). Origini 26: 121-153.

Ferrari, A., and Visentini, P. (eds.) (2002). Il declino del mondo neolitico, Museo Archeologico del Friuli Occidentale, Pordenone.

Fokkens, H., and Harding, A. (eds.) (2013). The Oxford Handbook of the European Bronze Age, Oxford University Press, Oxford.

Fowler, C., Harding, J., and Hofmann, D. (eds.) (2015). The Oxford Handbook of Neolithic Europe, Oxford University Press, Oxford.

Larocca, F. (ed.) (2005). La miniera preistorica di Grotta della Monaca (Sant'Agata di Esaro, Cosenza), Centro Regionale di Speleologia 'E. dei Medici,' Roseto Capo Spulico Stazione.

Martinelli, M. C., and Spigo, U. (eds.) (2001). Studi di preistoria e protostoria in onore di Luigi Bernabò Brea, Regione Sicilia, Palermo.

Martini, F. (ed.) (2006). La cultura del morire nelle società preistoriche e protostoriche Italiane dal Paleolitico all'età del Rame, Istituto Italiano di Preistoria e Protostoria, Firenze.

Nicolis, F. (ed.) (2001). Bell Beakers Today, Provincia Autonoma di Trento, Trento.

Pandolfi, L., and Zamagni, B. (2000). La pietra verde in Toscana: I dati sulle analisi delle provenienze. In Tozzi, C., and Weiss, M. C. (eds.), Le premier peuplement olocenes de l'aire Corso-Toscane, Edizioni ETS, Pisa, pp. 245-248.

Silvestrini, M. (ed.) (2000). Recenti acquisizioni, problemi e prospettive della ricerca sull'Eneolitico dell'Italia centrale, Regione Marche, Ancona.

Tarantini, M., and Galiberti, A. (2011). Le miniere di selce del Gargano, VI-III millennio aC Alle origini della storia mineraria europea, All'Insegna del Giglio, Florence.

Publisher's Note Springer Nature remains neutral with regard to jurisdictional claims in published maps and institutional affiliations. 